Association for Information Systems AIS Electronic Library (AISeL)

GlobDev 2011

Proceedings Annual Workshop of the AIS Special Interest Group for ICT in Global Development

$12-3-2011$

\title{
Mobile Money and Payment: a literature review based on academic and practitioner - oriented publications (2001 - 2011)
}

Eduardo Henrique Diniz

FGV-SP, eduardo.diniz@fgv.br

João Porto de Albuquerque

University of Sao Paulo, jporto@icmc.usp.br

Adrian Kemmer Cernev

FGV, Adrian.Cernev@fgv.br

Follow this and additional works at: http://aisel.aisnet.org/globdev2011

\section{Recommended Citation}

Diniz, Eduardo Henrique; Porto de Albuquerque, João; and Cernev, Adrian Kemmer, "Mobile Money and Payment: a literature review based on academic and practitioner - oriented publications (2001 - 2011)" (2011). GlobDev 2011. 7.

http://aisel.aisnet.org/globdev2011/7 


\title{
Mobile Money and Payment: a literature review based on academic and practitioner-oriented publications (2001-2011)
}

\author{
Prof. Eduardo Henrique Diniz \\ eduardo.diniz@fgv.br \\ FGV-EAESP - Brazil \\ Fundação Getulio Vargas
}

By

\author{
Prof. Adrian Kemmer Cernev \\ adrian.cernev@fgv.br \\ FGV-EAESP - Brazil \\ Fundação Getulio Vargas
}

KEYWORDS: mobile money, mobile payment, financial inclusion, developing countries, literature review

\begin{abstract}
The use of mobile technology has become widespread with astonishing speed all over the world, particularly among the poor. The more mobile phones go to the hands of people who formerly lacked access to financial services, the more the notions of mobile money, mobile payment and mobile banking become pervasive as a means of financial inclusion. Although there are more than 120 mobile money projects deployed in about 70 emerging markets (Beshouri et al. 2010), mobile payment has only taken off in a limited number of countries. This failure to disseminate a service with such a huge potential worldwide, shows that the reasons for the successful cases are not clearly understood, and as a result, are not being easily replicated. This paper seeks to fill this knowledge gap by providing a comprehensive literature review, which attempts to analyse significant experiences in this field, especially in developing countries. An investigation has been carried out of both academic, peer-reviewed articles and the available non-peer-reviewed practitioner-oriented publications, (a total of 196 papers - 94 peer-reviewed and 92 non-peerreviewed - published in the period 2001-2011) to obtain information related to the actors and institutions involved in mobile money initiatives. In other words, the study addresses the
\end{abstract}


following questions: what is the driving-force behind these initiatives, what are the obstacles and the social and economic implications of their implementation. Thus, the aim of this review is to map out the existing knowledge on mobile money by pointing out the main sources of information on the subject, and defining the topics that are most frequently researched. In addition, it examines which locations most studies focus on, and which methodologies are being applied to these studies, as well as the determining factors and contexts of the published studies.

\section{ACKNOWLEDGEMENTS}

We would like to thank IDRC - International Development Research Centre for supporting this research, as well as our partners in this research project from STRO - Social Trade Organisation, for the inspiring discussions and helpful suggestions. Also, we thank Vithor Gomes Bertalan, Micheli Rogalski and Fábio Krauss Stabel who helped us on the searching and categorizing of the analyzed papers. 


\section{INTRODUCTION}

The rapid rise in the growth of mobile technology throughout the world is a phenomenon that has been particularly remarkable among poor people, largely because of the prepaid model. As a result, all classes of society now have access to financial services as people become increasingly familiar with a mobile-money system.

In fact, mobile technology, viewed as a payment or banking channel, has the potential to allow two important questions to be addressed at the same time: on the demand side, it represents an opportunity for financial inclusion among a population that is underserved by traditional banking services. On the supply side, it opens up possibilities for financial institutions to deliver a great diversity of services at low cost to a large clientele of the poorest sections of society and people living in remote areas.

Although there are more than 120 mobile money projects being undertaken in about 70 emerging markets (Beshouri et al. 2010), mobile payment has only become a normal practice in a few countries, despite its huge potential. The lack of worldwide dissemination of a service with such a huge potential shows that successful cases are not clearly understood, and as a consequence, are not being easily replicated. This suggests that lessons are not being learnt from the places where the system has been successfully adopted. Furthermore, we suspect that the obstacles to its adoption in most countries are not being investigated deeply enough to allow implementation strategies to be employed on the basis of reliable business models. If these issues can be clarified, the potential social and economic impacts of mobile money can be more effectively measured and this can persuade policy-makers to create favourable regulatory environments for fostering the practice of digital payments.

In view of the importance of mobile money and payment initiatives, and the gaps in the current state of knowledge in the field, the objective of this paper is to provide a knowledge base on mobile money, based on a comprehensive literature review, and can be employed to identify significant experiences, together with the models being deployed around the world, especially in developing countries. Although there are literature reviews currently available both in the general context of mobile payment (Dahlberg et al., 2008) and in the field of mobile financing in developing countries (Duncombe and Boateng, 2009), the present work focuses on mobile payment/mobile money (as opposed to mobile financing in general) with a special stress on local 
development (but not limited to works that deal with development or developing countries). This article also updates and substantially expands the existing literature reviews on the subject. While Dahlberg et al. analysed 73 peer-reviewed papers, and Duncombe and Boateng reviewed 43 research papers (17 peer-reviewed and 23 non-peer-reviewed), the present review examines a total of 196 papers (94 peer-reviewed and 92 non-peer-reviewed) published between 2001and 2011.

The remainder of this paper is structured as follows: Section 2 outlines the theoretical background for this paper; Section 3 describes the methodology employed. Following this, the results are analysed in Section 4. Lastly, Section 5 discusses the results and makes some concluding remarks for the paper.

\section{CONCEPTUAL BACKGROUND}

Financial services provided through digital mobility technologies have multiple configurations, goals, and characteristics. Depending on the combination of agents, technologies and objectives, they may have banking features, which are known as mobile banking. They may also have transaction payment features, which are recognized as mobile payments. Finally, they may also replicate the concept of money with digital features, which is then called mobile money.

However the definitions of these concepts are not rigid and their delimitations are not very clear. In fact there is a considerable confusion with regard to the terms which are often used freely, regardless of their original meanings. This is the case with mobile payments: it may refer to bill payments, acquisition payments, or a transfer of financial resources or money between economic agents, and still come into the banking domain. In certain contexts, other concepts would be more appropriate, like mobile money, mobile transfer and/or mobile banking.

This confusion of terms is not restricted to mobile services, but also to their objectives. For example, the term "bankarization" has been used as a synonym for financial inclusion or even economic inclusion, although these concepts are quite distinct.

The wide use of these inaccurate definitions led us to establish an initial conceptual basis, to support the literature review. It should be stressed that the definitions given below are not the results of the review carried out in this paper, but was prepared as a preliminary phase on the basis of related work (Jenkings et al, 2008; Laukkanen et al., 2008; Shen, 2011). 
Table 1: Definition of the main concepts employed in this research study

\begin{tabular}{|c|c|}
\hline Concept & Definition \\
\hline $\begin{array}{c}\text { Mobile } \\
\text { transactions }\end{array}$ & $\begin{array}{l}\text { This refers to transactions carried out through mobile technologies and devices. In } \\
\text { addition to mobile payments, it includes every kind of mobile transaction offered by } \\
\text { technology, whether it involves financial values or not. }\end{array}$ \\
\hline $\begin{array}{c}\text { Mobile } \\
\text { payments }\end{array}$ & $\begin{array}{l}\text { Mobile payments include payments made or enabled through digital mobility } \\
\text { technologies, via handheld devices, with or without the use of mobile telecommunications } \\
\text { networks. These payments are digital financial transactions, although not necessarily } \\
\text { linked to financial institutions or banks. There are several models of mobile payments that } \\
\text { are currently employed worldwide. }\end{array}$ \\
\hline $\begin{array}{c}\text { Mobile } \\
\text { banking }\end{array}$ & $\begin{array}{l}\text { Mobile banking can be understood as a set of mobile banking services, involving the use } \\
\text { of portable devices connected to telecommunications networks that provide users with } \\
\text { access to mobile payments, transactions and other banking and financial services linked to } \\
\text { customer accounts, with or without the direct participation of traditional banking } \\
\text { institutions. This concept can also be regarded as the banking channel through which the } \\
\text { digital mobile services are provided by the institutions to the ir clients, i.e. by integrating } \\
\text { the concepts of service and channel. }\end{array}$ \\
\hline \multirow{2}{*}{$\begin{array}{l}\text { Mobile } \\
\text { money }\end{array}$} & $\begin{array}{l}\text { Electronic money - being essentially digital - has attributes related to mobility and } \\
\text { portability, and is equivalent to mobile-money or mobile-cash. It can be differentiated } \\
\text { from other means of electronic payment (such as credit cards, debit cards, smart cards, } \\
\text { etc.) because of its ability to replicate the essential attributes of traditional money, such as: } \\
\text { liquidity, acceptability and anonymity. }\end{array}$ \\
\hline & $\begin{array}{l}\text { Mobile money may be related to mobile wallet, which refers to a digital repository of } \\
\text { electronic money developed and implemented on mobile devices, allowing peer-to-peer } \\
\text { transactions (P2P) between mobile devices (M2M) from users of the same service. It is } \\
\text { similar to a normal phys ical wallet and is able to store money and credit and debit cards. }\end{array}$ \\
\hline
\end{tabular}

\section{METHODOLOGY}

This work is based on literature review, aiming to contribute to the progress of a specific substantive domain, as recommended by Bem (1995) and Webster and Watson (2002).

The first phase of the research consists of a comprehensive survey of the published literature on the question of "Mobile Money and Local Development". The main objective is to map out the current state of knowledge on mobile means of payment and the bearing they have on social development, as reflected in relevant research publications. Since developments in this area have been greatly influenced by the activities of practitioners, in addition to traditional 'academic' sources (peer reviewed journals and conference papers), it is also important to take account of practitioner-oriented, non-peer reviewed sources (such as consultant's reports, official reports, and other occasional and published papers) (cf. Duncombe and Boateng, 2009). 
Hence, the aim of this mapping of the existing literature is to identify what has been published about the subject (i.e. different contexts and research results), how the research has been conducted (i.e. the methodological approaches employed), and why they have been produced (i.e. the underlying reasons and main objectives), as well as the question of where the studies are targeted (i.e. the geographical locations).

In the pursuit of this goal, the search for relevant publications was divided into two subgroups: (a) papers in peer-reviewed, indexed journals and conference proceedings; (b) publications from non-peer-reviewed, practitioner-oriented sources. The methodological procedures employed for each of these groups are correspondingly described in the following sections.

\subsection{Peer-reviewed publications}

In the case of the peer-reviewed publications, the strategy adopted to search for relevant publications was a keyword-based search in the most important academic reference and re search indexes, databases, and digital libraries. As a first step, the terms "mobile money" and "mobile payment" were defined as keywords that might be present in the title or the abstract of relevant peer-reviewed journal and conference publications. The sources for this search, along with the corresponding number of papers found for each of the selected keywords, are shown in Table 2.

After examining the abstracts of the articles that resulted from the first stage of the search outlined above, only those articles were selected that came within the scope of the research - "the impact of mobile money on local development". Most of those articles contain the keywords, but have no direct relation to the scope of the research (e.g. they only mention the keywords being sought en passant whilst discussing a different topic). As the result of this filtering process, a list of 63 relevant articles was selected for closer examination.

After examining the abstracts of the articles that resulted from the first stage of the search outlined above, only those articles were selected that came within the scope of the research - "the impact of mobile money on local development". Most of tho se articles contain the keywords, but have no direct relation to the scope of the research (e.g. they only mention the keywords being sought en passant whilst discussing a different topic). As the result of this filtering process, a list of 63 relevant articles was selected for closer examination. 
Table 2: Results of the first search for indexed peer-reviewed publications

\begin{tabular}{|l|l|c|}
\hline \multirow{2}{*}{ Source } & Keyword & Res ults \\
\hline \multirow{2}{*}{ ACM Digital Library } & mobile money & 42 \\
\cline { 2 - 3 } & mobile payment & 346 \\
\hline \multirow{2}{*}{ AIS Eletronic Library - AISEL } & mobile money & 491 \\
\cline { 2 - 3 } & mobile payment & 403 \\
\hline \multirow{2}{*}{ CAPES database 1} & mobile money & 242 \\
\cline { 2 - 3 } & mobile payment & 240 \\
\hline \multirow{2}{*}{ EBSCO Academic Search Premier } & mobile money & 10 \\
\cline { 2 - 3 } & mobile payment & 49 \\
\hline \multirow{2}{*}{ EBSCO ISTA } & mobile money & 0 \\
\cline { 2 - 3 } & mobile payment & 2 \\
\hline \multirow{2}{*}{ IEEExplore } & mobile money & 231 \\
\cline { 2 - 3 } & mobile payment & 449 \\
\hline INFORMS - Information Systems & mobile money & 115 \\
\cline { 2 - 3 } Research & mobile payment & 17 \\
\hline \multirow{2}{*}{ ISI Web of Knowledge } & mobile money & 19 \\
\cline { 2 - 3 } & mobile payment & 442 \\
\hline \multirow{2}{*}{ SCOPUS } & mobile money & 7 \\
\cline { 2 - 3 } & mobile payment & 281 \\
\hline \hline \multirow{2}{*}{ Total } & & $3386 *$ \\
\hline
\end{tabular}

* The total includes papers that are repeated in various sources and contain both keywords.

An initial analysis of the 63 selected articles revealed that most deal with the situation of developed countries and rarely address social and development issues. For this reason, a set of another 15 journals (listed in Table 3) was selected to cover sources that are not indexed in the databases referred to above, but are directly related to Information and Communication Technologies and Development, and thus could better address the project focus on local development.

A new search was undertaken in the journals from Table 3 using the same keywords "mobile payment" and "mobile money", but also supplemented with the search string "(financial inclusion) AND mobile", so as to maximize the coverage of development-related works. On the basis of this new search, 55 articles were found. The abstract of these articles was screened to select only those articles that would come within the scope of "the impact of mobile money on local development", which resulted in 31 new articles being selected.

\footnotetext{
${ }^{1}$ CAPES [Federal Agency for Support of Post-graduate Education] is a department of the Brazilian Ministry of Education that is responsible for post-graduate education programmes. It currently keeps a database of more than 29 thousand journals, the complete papers of which are available for all public higher education institutions (http://periodicos.capes.gov.br).
} 
Together with the 63 articles selected in the previous stage, a final set of 94 articles was selected for more detailed analysis, as explained in the following section. The complete list of peerreviewed papers analysed can be found in Annex 1.

Table 3: Journals with a specific focus on ICT for development

\begin{tabular}{|c|l|}
\hline 1 & Aournal Title \\
\hline 2 & African Journal of Information \& Communication Technology \\
\hline 3 & African Journal of Information Systems \\
\hline 4 & Asian Journal of Communication \\
\hline 5 & $\underline{\text { Asian Journal of Information Management }}$ \\
\hline 6 & $\underline{\text { Asian Journal of Information Technology }}$ \\
\hline 7 & $\underline{\text { Electronic Journal of Information Systems in Developing Countries }}$ \\
\hline 8 & $\underline{\text { Information Development }}$ \\
\hline 9 & $\underline{\text { Information Technologies and International Development }}$ \\
\hline 10 & $\underline{\text { Information Technology for Development }}$ \\
\hline 11 & $\underline{\text { International Journal of Education and Development Using }}$ \\
\hline 12 & $\underline{\text { Information and Communication Technology }}$ \\
\hline 13 & $\underline{\text { and Human Development }}$ \\
\hline 14 & $\underline{\text { International Journal on Advances in ICT for Emerging Regions }}$ \\
\hline 15 & $\underline{\text { South African Journal of Information Management }}$ \\
\hline
\end{tabular}

\subsection{Non-peer-revie wed publications}

The choice of the sources for non-peer-reviewed publications was made in two stages: first, the researchers listed the available publications in the web portals of the organizations that are directly related to the topic "Mobile Money" and which were already known to the researchers. During the analysis of the articles carried out in this first stage, the additional research sources that were referenced in the articles were selected for a second stage of the analysis, in which a search using Google Scholar search engine (http://scholar.google.com) was conducted, that led to other articles that have not yet been analysed. 
Since many of these sources have a large knowledge base with an associated keyword-based search mechanism, the same keywords were used that had been defined for the peer-reviewed publications (see Section 3.1). In this manner, more than 530 articles were identified and ordered in degrees of importance and in accordance with an initial evaluation. The search for articles and materials was pursued until the researchers could not find any further publications that could be linked to the project goal.

In the CGAP knowledge base, the articles were analysed in the order in which they appear in the search engine's response until the 100th position. In each of these articles, other relevant features were found and analysed, such as hyperlinks to CGAP (both internal and external). Each article contained from zero to five other relevant references. Thus, more than 200 articles were effectively analysed in the CGAP database during this stage of the work.

Table 4: Results of the search for non-peer-reviewed publications

\begin{tabular}{|l|c|}
\hline Source & Number of articles \\
\hline CGAP & 200 \\
\hline Gartner Group & 40 \\
\hline GSM Association & 50 \\
\hline Google Scholar (mobile money) & 100 \\
\hline Google Scholar (e-money) & 100 \\
\hline Others & 40 \\
\hline \hline Total & $\mathbf{5 3 0}$ \\
\hline
\end{tabular}

There is no search engine inside the GSMA portal that is effective enough to allow us to, replicate the method described above. Thus, the content (web pages showing cases and discussing the subject) was analysed during the visits to each relevant section. As a result, nearly 50 articles were identified and analysed in this portal. The number of analysed articles in each source, as a result of this procedure, is shown in Table 4. Out of these 530 publications (including articles, white papers, webpages and multimedia content), 92 were selected to form the non-peerreviewed corpus. The complete list of non-peer-reviewed papers can be found in Annex 2 .

\subsection{Analytical Procedures}

For a detailed analysis of the corpus of 94 selected articles, the first step was to define the dimensions of the analysis, i.e. the dimensions through which each of the articles would be classified. The initial set of dimensions was drawn from a list contained in the project, which in 
turn was obtained from a 'brainstorming' session by the researchers in the planning stage. This initial list was subjected to a validation test in which three different researchers read each of three papers from the corpus and tried to classify them in accordance with the dimensions. Following this, the results were shared and the suitability of the dimensions was discussed at a meeting; this led to a final set of 17 dimensions, listed in Table 5.

Table 5: List of Dimensions from the Analysis

\begin{tabular}{|c|c|c|}
\hline \multicolumn{2}{|r|}{ Dimension } & Meaning \\
\hline 1 & Title & Title of the article \\
\hline 2 & Author(s) & Authors of the article \\
\hline 3 & Institution(s) & Institutions of the authors \\
\hline 4 & Year of Publication & Year of publication \\
\hline 5 & Source Title & Title of the Journal or Conference in which the paper appears \\
\hline 6 & Type of Paper & Journal/Conference \\
\hline 7 & Location & Geographical location of the object of study \\
\hline 8 & Motivation/Objective & Main goal of the article \\
\hline 9 & Actors & Most important groups of actors/institutions mentioned \\
\hline 10 & $\begin{array}{l}\text { Inter-organizational } \\
\text { Processes }\end{array}$ & Main processes that link the actors together \\
\hline 11 & $\begin{array}{l}\text { Technological } \\
\text { Infrastructure }\end{array}$ & $\begin{array}{l}\text { Statements about the technological infrastructure of the MM } \\
\text { initiatives }\end{array}$ \\
\hline 12 & Services & Services offered in an MM init iative \\
\hline 13 & $\begin{array}{l}\text { Socioeconomical } \\
\text { Implications }\end{array}$ & Socioeconomical Implications of MM \\
\hline 14 & Legal Factors & Regulations and legal factors involved \\
\hline 15 & $\begin{array}{l}\text { Obstacles to } \\
\text { Implementation }\end{array}$ & Obstacles to the implementation of MM \\
\hline 16 & Methodology & Methodology employed in the study \\
\hline 17 & Relevant Results & Summary of the most relevant results \\
\hline
\end{tabular}

Each paper in the corpus was analysed by a researcher and tabulated in each of the 17 analytical dimensions listed in Table 5. This tabulation was conducted by picking quotations from the corresponding paper that matched a certain dimension and/or adding the researchers' own comments. The only dimensions that were filled in were those in which the paper made significant contributions.

The final stage consisted of an analysis of the resulting tabulation with the aim of identifying common features and groups of similar articles in the different dimensions. As a result, the five dimensions listed in Table 6 were selected for categorization. In Table 6, the first item includes the reference dimensions, i.e. the dimensions that are used to identify each paper: who wrote it (author), when (year), where it was produced (institution), and where it appears (source title and 
type of publication). The criterion for the selection of the remaining dimensions (2 to 5) was the prospect they offered of producing significant groupings, i.e. dimensions in which the papers could be put into subgroups that contained more than five similar papers. Each of these subgroups was then identified by a category name, which was inductively defined from the analysis of the tabulation.

Finally, each peer-reviewed paper in the corpus was coded by means of the categories in Table 6. The final codification was thus used as a basis for producing the graphics and for drawing the conclusions outlined in Section 4. During the final stage of the analysis, i.e. the categorization, the researchers realized that the categories inductively defined for the peer-reviewed corpus were not very applicable to the non-peer-reviewed publications. Hence, there is a need for a new categorization, which is planned for further work in the future. Furthermore, while undertaking the literature review, we also detected that there are a significant number of papers that deal with the topics on mobile payment/ money but use the term "mobile banking", and thus had been left out of the current review. This variation in terminology should also be taken into account in any future work.

Table 6: List of dimensions and corresponding categories

\begin{tabular}{|l|l|}
\hline $\begin{array}{l}\text { 1. Author(s), Institution(s), Year of } \\
\text { Publication, Source Title, Type of }\end{array}$ & 4. Methodology \\
Publication: reference dimensions & 4.1 Case study: empirical research \\
& 4.3 Survey \\
2. Location: & 4.4 Experiment \\
2.1 USA, Europe and Japan & 4.5 Focus groups \\
2.2 Africa & 4.6 Research design: development of new \\
2.3 Latin America & technology/processes \\
2.4 China and India & 4.7 Theoretical essay \\
2.5 Other Asian/Oceania Countries & 4.8 Review of existing research \\
& \\
3. Application Context & 5. Barriers to implementation \\
3.1 Consumer adoption & 5.1 Technological/security/limitations of user \\
3.2 Merchant adoption & interface \\
3.3 Market analysis & 5.2 Lack of Infrastructure (electricity, mobile \\
3.4 Technical frameworks/approaches & coverage etc.) \\
3.5 Technological factors & 5.3 Unwillingness of consumers and merchants to \\
3.6 Analysis of failures & adopt / Lack of trust \\
3.7 MM for the BoP & 5.4 Lack of Standards / interoperability \\
& 5.5 Regulations / Legal framework \\
& 5.6 Problems of Scale / Network Effect \\
& 5.7 High Costs / Overhead \\
& 5.8 Lack of cooperation between market players \\
& 5.9 Lack of knowledge of m-money/m-payment \\
& 5.10 Low Levels of Literacy and Financial Education \\
\hline
\end{tabular}


Especially for the analyses of the non-peer-reviewed articles, we also used the "Tag Clouds" method. It was mainly used to allow an analysis to be conducted of the items for which we could not find a reasonable categorization. A Tag Cloud is a graphical representation of words and terms, and is used to draw attention to a feature that is more expressive than others, and also to facilitate access to related content, by providing a visual summary of the contents of the database (Sinclair \& Cardew-Hall, 2008). In our case, the criterion for the relative highlighting of terms was the frequency with which the terms appear in the chosen quotations for a certain analytical dimension, so that the generated Tag Clouds allow us to become familiarized with the main issues dealt with in the analysed articles.

\section{RESULTS}

Figure 1 shows the distribution of the papers that were analysed for this review in the period from 2002 until the first half of 2011 (although the timeframe defined for the review was 2001-2011, the search results did not include any paper published in 2001). It clearly shows that mobile payment/money is a recent phenomenon, a fact that is borne out by the significant and continuous increase in the number of publications since 2007. It should be noted that although the review was only able to cover the first half of 2011 (the current point in time), there has already been a large number of papers on the subject published this year, especially from practitioner-oriented sources.

Figure 1: Distribution of the analysed papers over a period of time

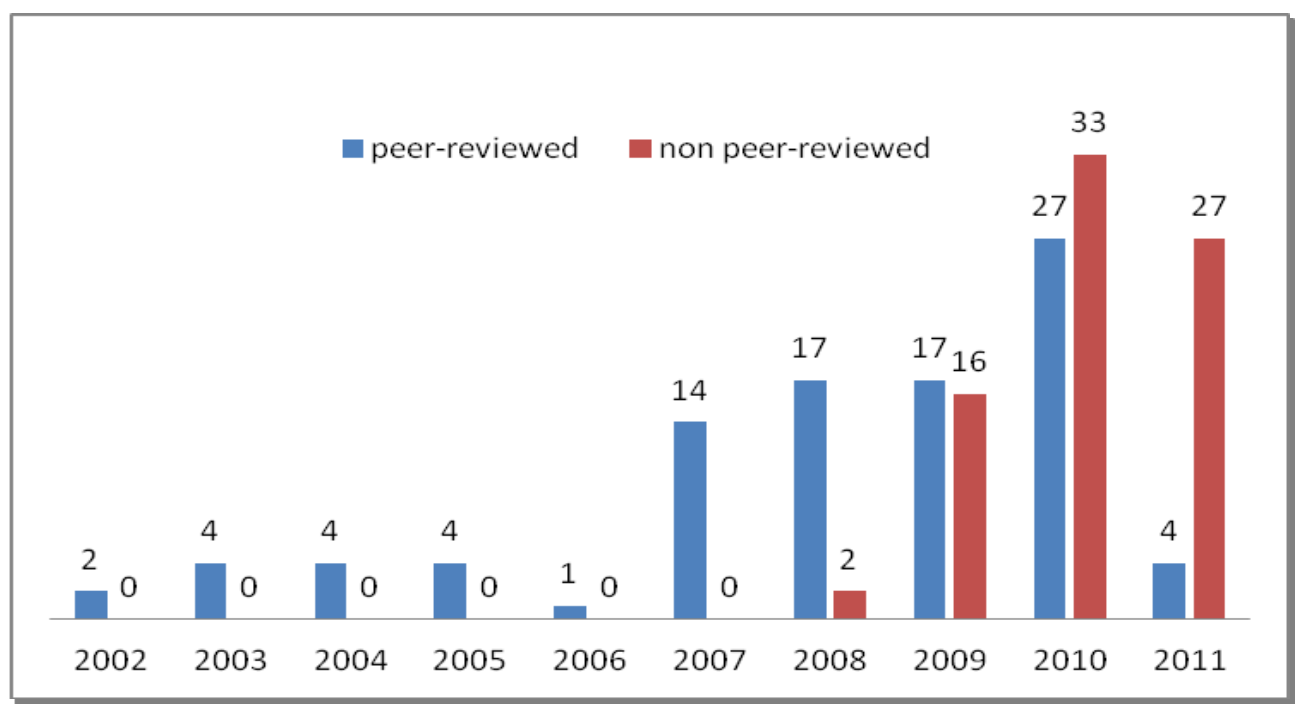


In addition, the analysis of non-peer-reviewed publications only began in 2008 . This can be explained, on the one hand, by the fact that the sources for these publications were mostly web sites, which tend to focus on updated, recent articles rather than on historical records of past publications. On the other hand, the selection process we used for non-peer-reviewed publications (see Sect. 3.2) may also have prioritized more recent publications, since they are usually ranked higher in the web search engines used.

\subsection{Peer-reviewed papers}

The analysis of the selected peer-reviewed papers offers some interesting insights as regards the location of the studies published in the reviewed papers. On the top of the list is Kenya with 10 papers, which should not come as a surprise in the light of the success of the paradigmatic MPESA case. China is second in the ranking, with 9 papers, which can be explained by the large number of Chinese institutions publishing in the area. The list of countries analysed in 5 or 4 papers of the corpus includes Finland, India, the Philippines, South Africa, and USA. The Philippines and South Africa are most likely included because of their recent initiatives in mobile money /payment, while Finland, Ind ia and US A provide the context of the studies carried out by the prolific number of their institutions in the field. It should be pointed out that our attribution of location to a paper is not exclusive - i.e. it can handle two or more location categories at the same time; conversely, not all the papers can be attributed to a location category but only those that mention a specific country/region as their object of study.

Table 7: Location of studies in peer-reviewed papers (categorized)

\begin{tabular}{|l|c|}
\hline Location & Pape is \\
\hline USA, Europe and Japan & 26 \\
\hline Africa & 14 \\
\hline Latin America & 1 \\
\hline China and India & 22 \\
\hline Other Asian/Oceania Countries & 21 \\
\hline
\end{tabular}

By analyzing the location of the studies grouped into categories (Figure 2 and Table 7), it can be seen that what is mainly addressed is the situation of developed countries (in the category of countries like Europe/USA/Japan) with 26 papers, followed by a significant number of articles (22) that address today's two largest emerging economies (China and India); additionally, 21 papers study many other different countries in Asia and Oceania. As for the situation of 
developing countries, African countries are cited in 14 papers, while - quite surprisingly - only one of the analysed papers was targeted at Latin America.

Figure 2 shows the distribution of the location of the studies in the analysed papers of the specific period, and makes clear that the growing number of studies since 2007 (already referred to above) was accompanied by a trend which sought to broaden the spectrum of countries addressed, including more studies on China/India, and other Asian/Oceania countries. One of the most notably difficult is, Africa which has been included as an object of study in mobile payment/money articles since 2007, probably due to the spread of knowledge about the success of individual cases like Kenya.

Figure 2: Peer-reviewed papers: location of studies

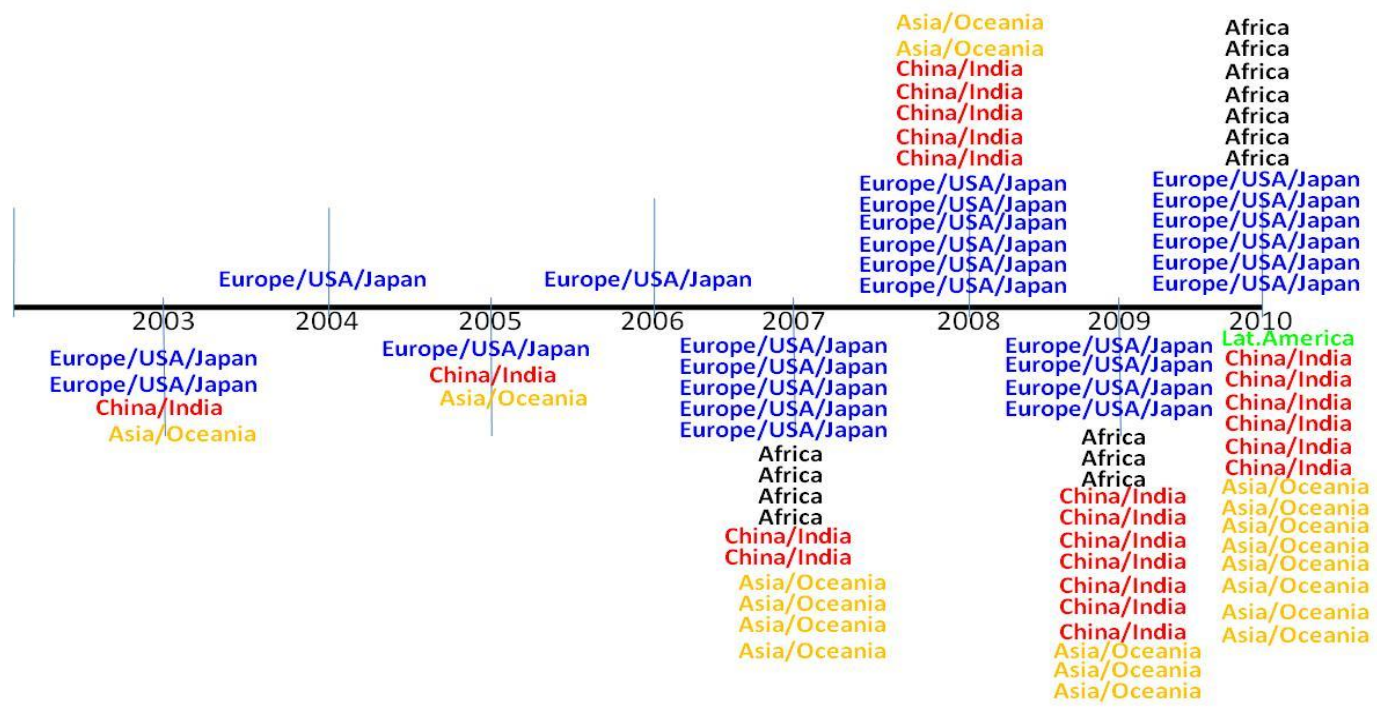

With regard to the methodology employed (Table 8), most of the peer-reviewed articles that were analysed, consist of essays (i.e. articles that set out and/or analyze a situation in a theoretical manner, without a more extensive discussion of specific cases and/or undertaking of other types of empirical research). Other methods that are used by many of the analysed articles include surveys (27 articles) and case studies (24 articles). The latter are subdivided into analyses based on self- conducted empirical research (13 articles) and case studies relying upon secondary data (11 articles). In this context, the term case study is broadly used to cover all kinds of analyses of specific cases (that are mostly countries), but do not always entail rigorous methods. In future work, it would be worth refining the analysis of these cases to evaluate the rigor of the research methods used, and to allow a more satisfactory estimate to be made of the power and extent of their conclusions. 
Table 8: Peer-reviewed papers: methodology of studies

\begin{tabular}{|l|c|c|}
\hline Methodology & pape is & $\%$ \\
\hline Case study: empirical research & 13 & $14 \%$ \\
\hline Case study: based on secondary data & 11 & $12 \%$ \\
\hline Essay & 32 & $34 \%$ \\
\hline Experiment & 1 & $1 \%$ \\
\hline Focus groups & 2 & $2 \%$ \\
\hline Research design: development of new technology / processes & 3 & $3 \%$ \\
\hline Review of existing research & 5 & $5 \%$ \\
\hline Survey & 27 & $29 \%$ \\
\hline
\end{tabular}

Table 9 makes a cross analysis between the methodology employed by the peer-reviewed papers analysed versus the location of their objects of study. Here, it is evident that most case studies, whether based on secondary data or on empirical research, were conducted in developed countries (9 in USA/Europe/Japan), although Africa also appears as a frequent location for case studies with 8 papers. As for China/India and Other Asian/Oceania countries, although in total the number of papers that deal with them is closer to USA/Europe/Japan (see Table 7), in terms of methodology they are distributed in a different way, since there are relatively fewer case studies on China/India (6 articles) and other countries in Asia/Oceania (5 articles) - in these two latter categories, surveys are most often relied on as the methodology. The complete absence of empirical studies of any kind on Latin America or Arab countries is remarkable.

Table 9: Peer-reviewed papers: methodology vs. location

\begin{tabular}{|l|c|c|c|c|c|}
\hline Methodology & $\begin{array}{c}\text { USA/Europe } \\
\text { /Japan }\end{array}$ & \multicolumn{2}{|c|}{$\begin{array}{c}\text { Africa } \\
\text { Ame rica }\end{array}$} & $\begin{array}{c}\text { China/ } \\
\text { India }\end{array}$ & $\begin{array}{c}\text { Asia/ } \\
\text { Oceania }\end{array}$ \\
\hline Case study: empirical research & 7 & 4 & 0 & 5 & 3 \\
\hline Case study: based on secondary data & 2 & 4 & 0 & 1 & 2 \\
\hline Essay & 7 & 4 & 0 & 6 & 2 \\
\hline Experiment & 0 & 0 & 0 & 0 & 1 \\
\hline Focus groups & 2 & 0 & 0 & 0 & 1 \\
\hline $\begin{array}{l}\text { Design research: develop. of new } \\
\text { technology }\end{array}$ & 0 & 0 & 0 & 1 & 0 \\
\hline Essay & 7 & 4 & 0 & 6 & 2 \\
\hline Review of existing research & 0 & 2 & 1 & 1 & 2 \\
\hline Survey & 6 & 3 & 0 & 8 & 10 \\
\hline
\end{tabular}


With regard to the main areas investigated by the surveyed studies, consumer adoption, market analysis and mobile money and payment for the poor are the most common issues addressed (see Table 10). Many of the consumer adoption studies commonly use theoretical models on 'technology acceptance' like TAM (Technology Acceptance Model) and its succeeding variations, to identify the factors that may influence the adoption of mobile money/payment technology. As for Market Analysis, this is a label that covers a wide range of studies that, in some ways, discuss the prospects and, forms of the mobile money/payment market and/or obstacles to it.

Table 10: Peer-reviewed papers: Key focus themes

\begin{tabular}{|l|c|c|}
\hline Context & pape is & $\%$ \\
\hline Consumer adoption & 29 & $30 \%$ \\
\hline Market analysis & 27 & $28 \%$ \\
\hline MM for the BoP & 23 & $24 \%$ \\
\hline Technical frameworks / approaches & 7 & $7 \%$ \\
\hline Merchant adoption & 4 & $4 \%$ \\
\hline Analysis of failures & 4 & $4 \%$ \\
\hline Technological factors & 3 & $3 \%$ \\
\hline
\end{tabular}

Figure 3: Peer-reviewed papers: Key focus themes

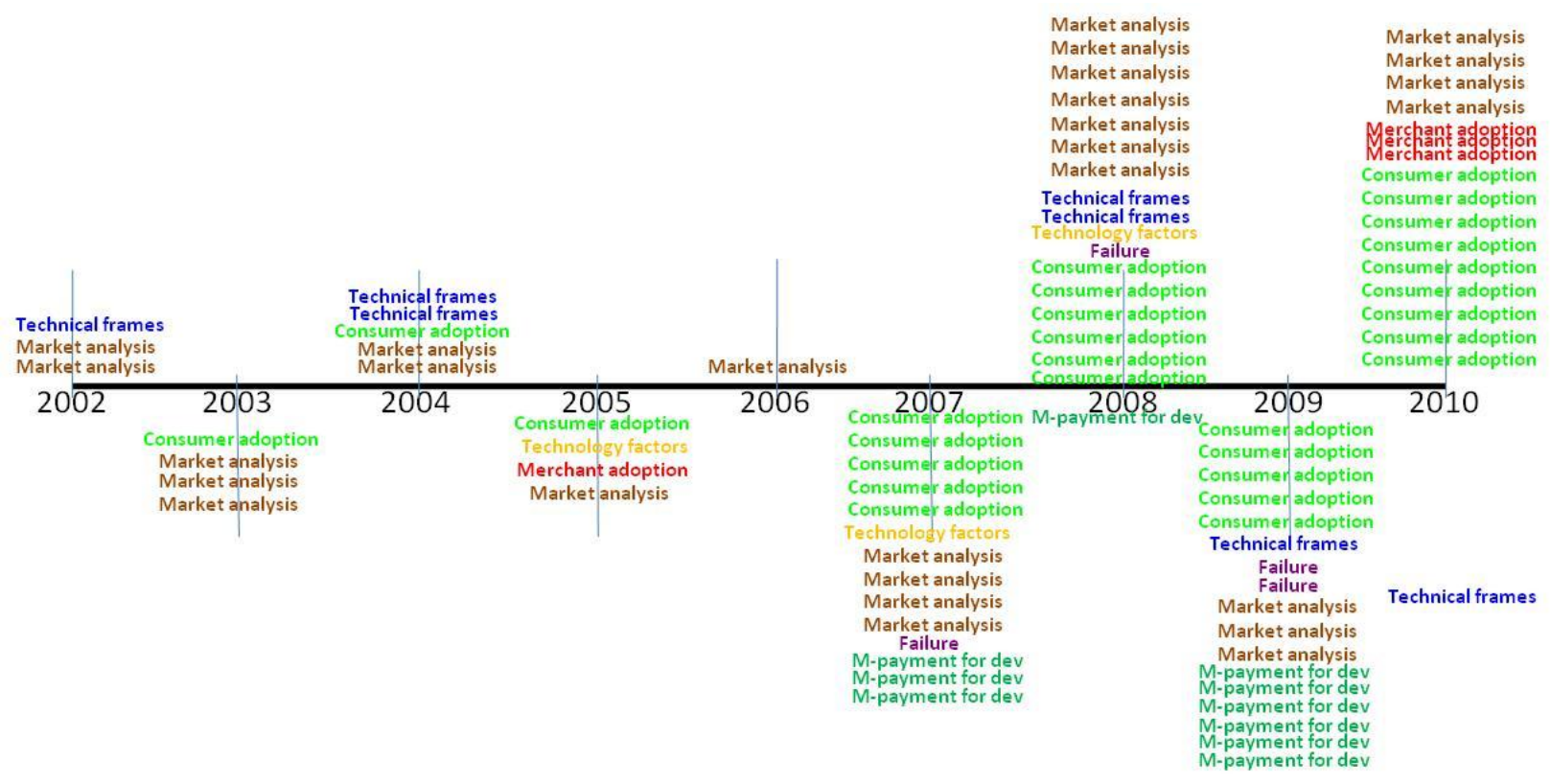


By analyzing the distribution over a period of time in Figure 3, it is clear that the way Mobile Money / Mobile Payment reaches the Bottom of the Pyramid (or is used for development) has been established as a serious issue since 2007, and coincides with the point in time at which research studies began covering typical developing countries (e.g. Africa, see Fig. 5) - a fact that may also be due to the widespread knowledge of the Kenyan case.

Only half of the analysed papers mention any obstacles to the implementation of mobile payment initiatives. The main drawbacks that are mentioned concern technological issues (e.g. security, interface design) and the unwillingness to adopt them (by consumers or merchants), each of them mentioned in 16 papers (Table 11). The lack of acceptable standards leading to interoperability problems, and a lack of knowledge of mobile payment are mentioned by 10 papers.

Table 11: Peer-reviewed papers: obstacles to implementation

\begin{tabular}{|l|c|c|}
\hline Obstacles to imple me ntation & pape is & $\%$ \\
\hline Technological/security / user interface limitations & 16 & $18 \%$ \\
\hline Lack of Infrastructure (electricity, mobile coverage etc.) & 5 & $6 \%$ \\
\hline Unwillingness of consumers and merchants to adopt / Lack of trust & 16 & $18 \%$ \\
\hline Lack of Standards / interoperability & 10 & $11 \%$ \\
\hline Regulations / Legal framework & 7 & $8 \%$ \\
\hline Problems of Scale / Network Effect & 6 & $7 \%$ \\
\hline High Costs / Overhead & 8 & $9 \%$ \\
\hline Lack of cooperation between market players & 4 & $5 \%$ \\
\hline Lack of knowledge of m-money / m-payment & 10 & $11 \%$ \\
\hline Low Levels of Literacy and Financial Education & 3 & $3 \%$ \\
\hline Other & 2 & $2 \%$ \\
\hline
\end{tabular}

A cross-analysis between obstacles to implementation and location of studies is shown in Table 12. An interesting - albeit understandable - result is that whereas in developed countries technological limitations and the unwillingness of consumers and/or merchants to adopt are mostly cited, in the case of African countries, regulations and high costs appear as the most important obstacles to implementation.

With regard to socioeconomic implications, the high degree of dispersion of the topics mentioned in the analysed papers, did not allow us to make a significant categorization. For this reason, we decided to offer a visual presentation of the socioeconomic implications in the form of a tag cloud generated from key phrases taken from the analysed publications (Fig. 4). 
Table 12: Peer-reviewed papers: obstacles to implementation vs. location

\begin{tabular}{|l|c|c|c|c|c|}
\hline Barrie rs & $\begin{array}{c}\text { USA } \\
\text { Europe } \\
\text { Japan }\end{array}$ & Africa & $\begin{array}{c}\text { Latin } \\
\text { Ame rica }\end{array}$ & $\begin{array}{c}\text { China } \\
\text { India }\end{array}$ & $\begin{array}{c}\text { Oceania } \\
\text { Asia }\end{array}$ \\
\hline $\begin{array}{l}\text { Technological / security / } \\
\text { user interface limitations }\end{array}$ & 6 & 2 & 0 & 3 & 7 \\
\hline $\begin{array}{l}\text { Lack of Infrastructure } \\
\text { (electricity, mobile coverage etc.) }\end{array}$ & 0 & 2 & 0 & 0 & 2 \\
\hline $\begin{array}{l}\text { Unwillingness of consumers and } \\
\text { merchants to adopt / Lack of trust }\end{array}$ & 6 & 2 & 0 & 1 & 5 \\
\hline $\begin{array}{l}\text { Lack of acceptable Standards / } \\
\text { interoperability }\end{array}$ & 4 & 2 & 0 & 2 & 3 \\
\hline Regulations / Legal framework & 1 & 4 & 1 & 2 & 1 \\
\hline Problems of Scale / Network Effect & 4 & 4 & 1 & 1 & 1 \\
\hline High Costs / Overhead & 1 & 0 & 0 & 2 & 0 \\
\hline $\begin{array}{l}\text { Lack of cooperation between market } \\
\text { players }\end{array}$ & 3 & 2 & 0 & 1 & 6 \\
\hline $\begin{array}{l}\text { Lack of knowledge of m-money / } \\
\text { m-payment }\end{array}$ & 0 & 0 & 0 & 0 & 0 \\
\hline $\begin{array}{l}\text { Low Levels of Literacy and Financial } \\
\text { Education }\end{array}$ & & 2 & 1 & 1 \\
\hline
\end{tabular}

The most significant terms include financial, services, access, (m-)payment, transfer, and banking. This could suggest that the expansion of access to financial services is one of the mostly cited socioeconomic implications of mobile payment systems.

Figure 4: Cloud of tags with Socioeconomic Implications

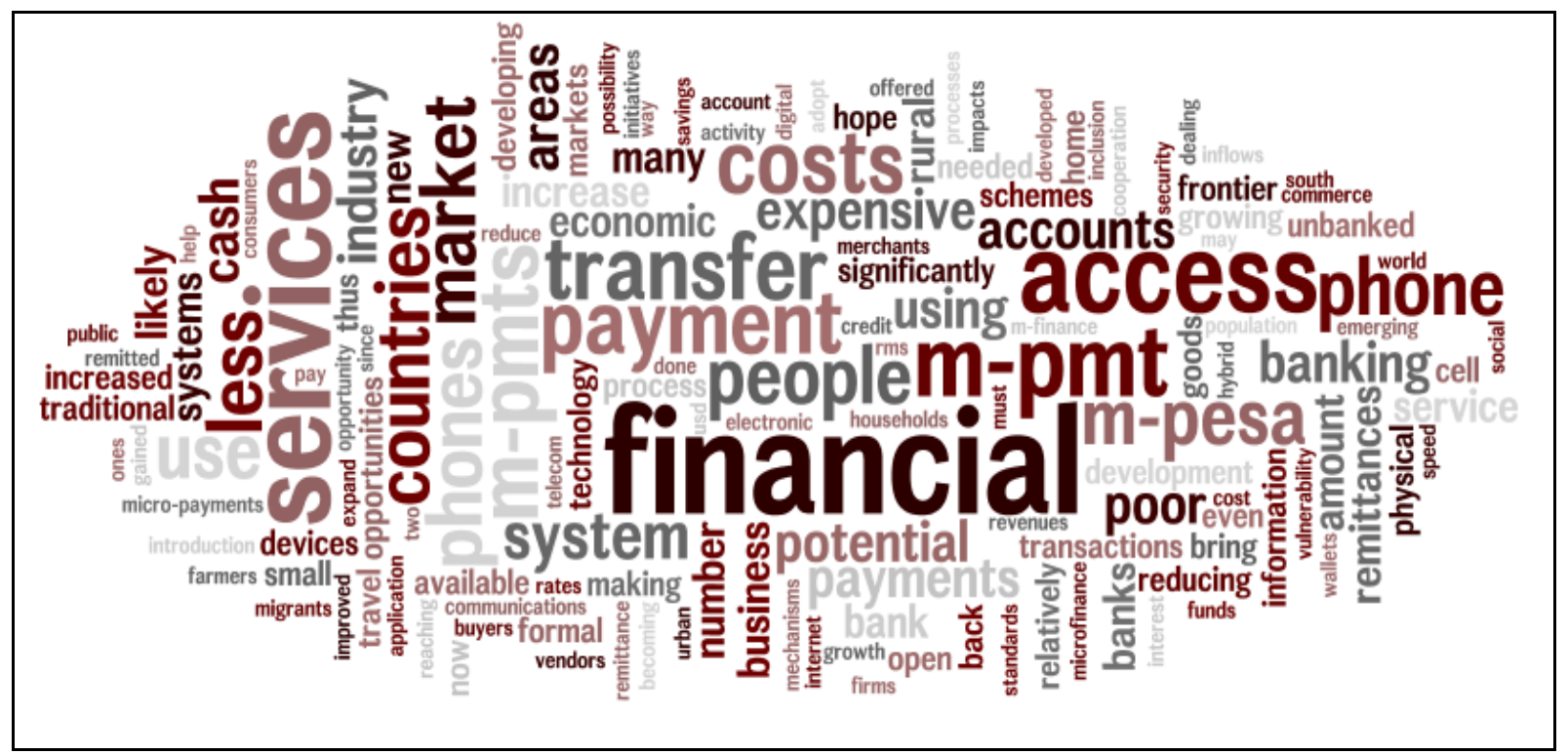




\subsection{Non peer-reviewed papers}

All the 92 non- peer-reviewed articles analysed at this stage of this study are dated from 2009 onwards. This suggests that the subject "mobile money" has achieved more importance in nonpeer-reviewed sources in recent years, following its appearance and recognised importance in the peer-reviewed articles.

The most significant sources of these articles were the CGAP and GSM Association. This is not surprising, since both organizations have activities concerned with "mobile money", and formed the starting- point of the data collection at this stage of the work.

In a preliminary stage, we analysed material taken from non- peer reviewed publications by means of the tag cloud method. Some analytical dimensions have been researched through transcripts taken from the articles, which made this preliminary session feasible.

Before generating the tag, we removed the words "mobile" and "money" in all the simulations, because they were used as keywords in the search for articles. We also grouped words that appeared to be written differently, such as "banks" which encompasses "bank", "Bank" and "Banks". This procedure was adopted for the most relevant words, but was unnecessary for less popular terms, since the goal of the cloud of tags is to display graphically the importance of the most common words.

Figure 5: Cloud of tags for the actors involved

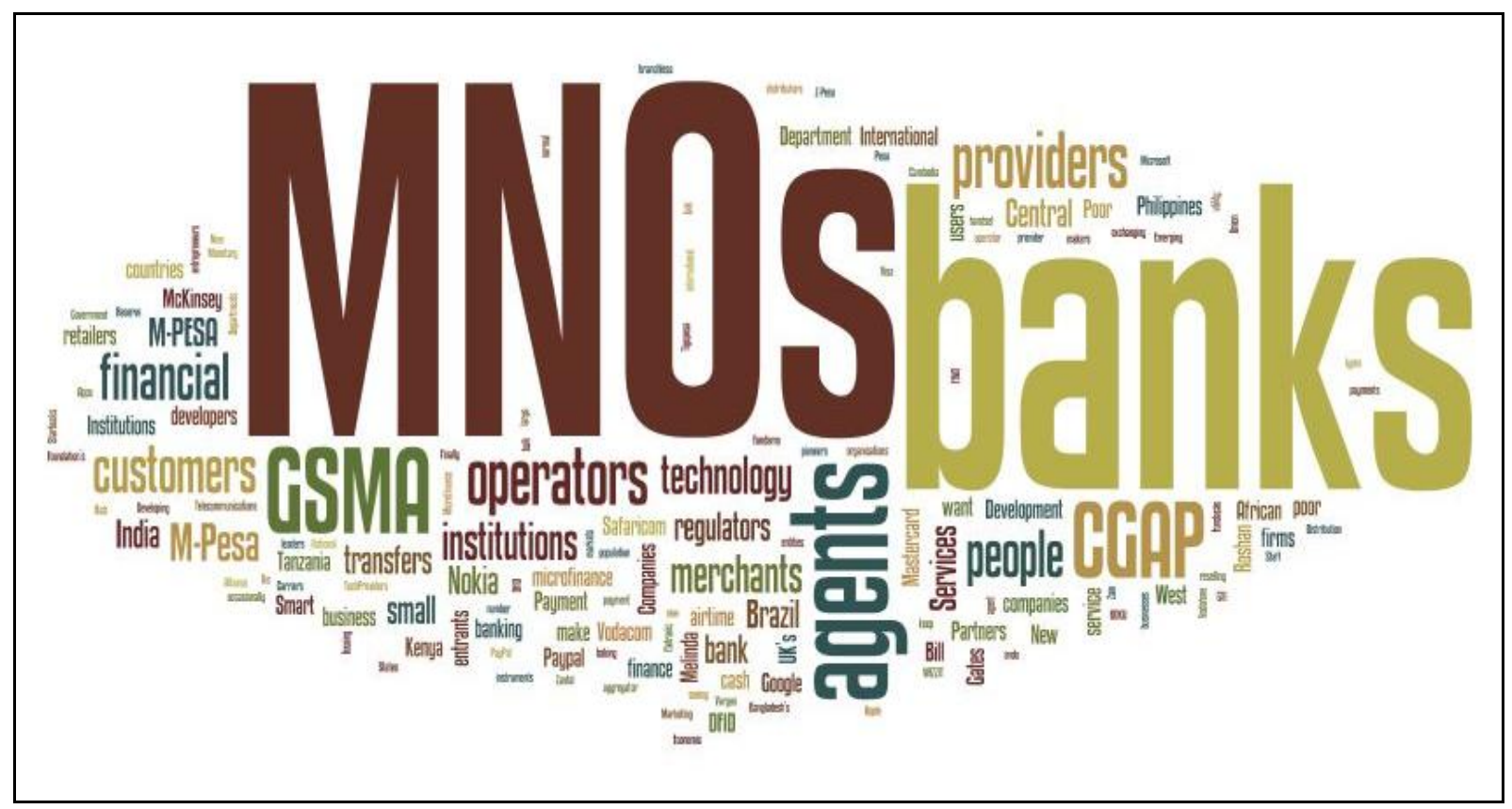


With regard to the actors involved, it is notable that the "MNOs" and "Banks" appear with greater emphasis, followed by "Agents" and the "CGAP" and "GSMA" organisations. This observation is not surprising, although, the fact the "users" and "customers" do not feature prominently is of great interest.

Moreover, when the term "Agents" is analysed in these articles, we understand that it applies to both the intermediaries in the business model of MNOs initiatives, and the distribution partners in branchless banking business models. In other words, the word "Actor" in the cloud tags has different meanings.

This analysis also shows that the dimension "Customers/Users" has been less discussed in these publications, suggesting that greater attention is paid to the suppliers or organizations involved. In fact, the articles suggest that the "Customers/Users" dimension has been shelved for "future research opportunities".

It was also striking that other agents that were often mentioned as being very important do not feature prominently, such as the Government and Regulations related to the legal environment.

Regarding the application context, we observed in Figure 6 that the transcripts also laid more emphasis on the words "services", "success", "country", "market" and "business". Moreover, it again highlighted the dimension of the suppliers (mainly the MNOs but also the banks).

Figure 6: Cloud of tags in the context of applications

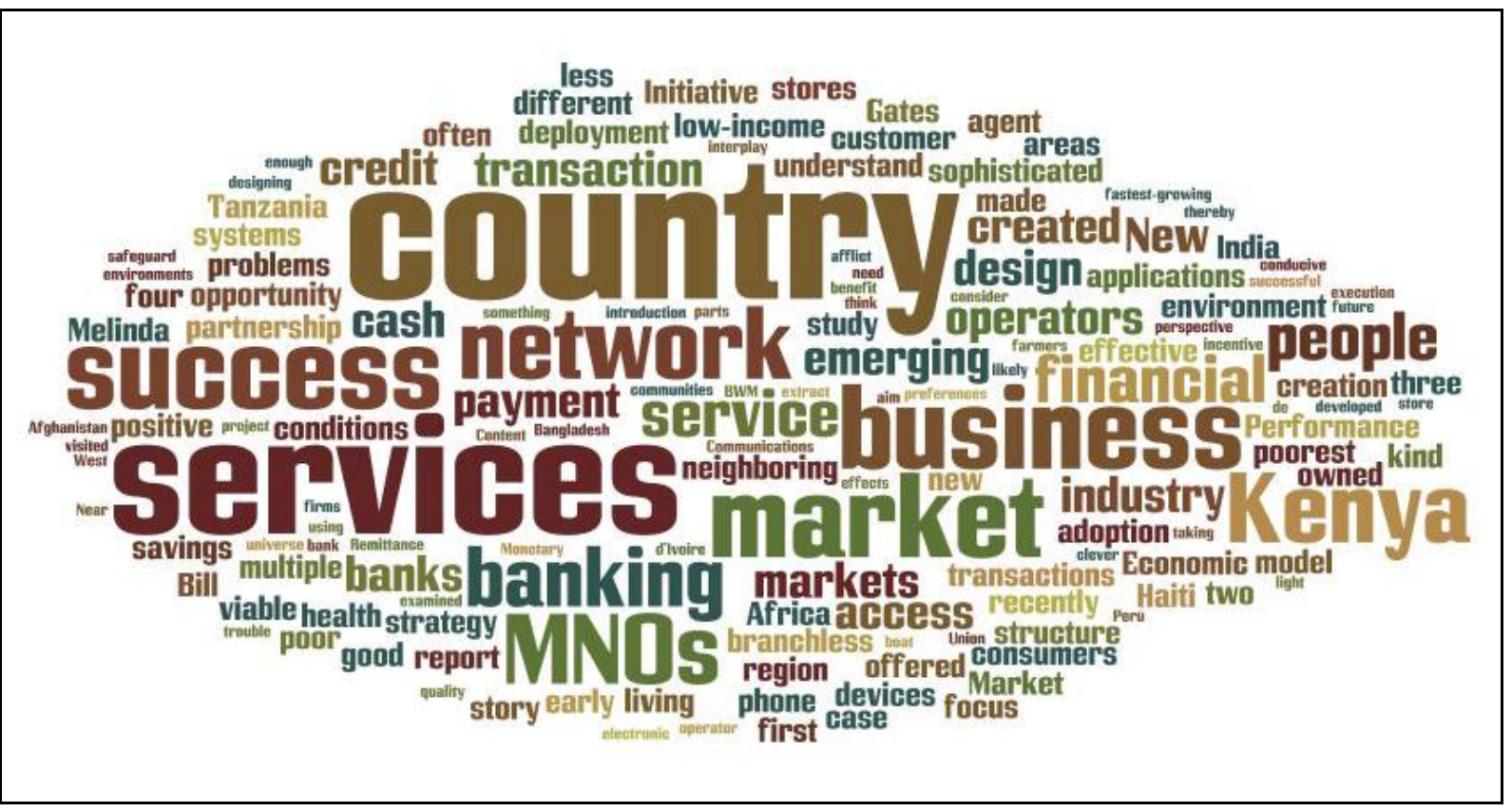


One of the curious findings is that the word "success" is given prominence. This may mean that tho se articles cover cases of success or initiatives related to the subject "mobile money", although few articles analyze the documented initiatives in a critical way.

When it comes to the obstacles to the implementation and success of the mobile money services, the non- peer-reviewed articles show that the key constraints mainly apply to the following categories:

- Users: user adoption and experience, mainly related to security, privacy, trust, fraud and risk perception. It also includes psychological inhibitions caused by the technology and new services.

- Business Models: business model problems arising from, restrictions and complexity, including obstacles to adoption and the need for an ecosystem with multiple operators and relations. This category also includes the remuneration and commissions of agents paid to resellers (the problem may be either the large or small amount of commission paid).

- Suppliers: lack of infrastructure and service coverage (availability and capillarity); need for new skills on the part of the agents; competition with traditional (formal and informal) service providers; and lack of banking expertise.

- Price/Cost: on the user side, the constraint may be the cost and price of devices and services; on the supplier side, the problem is the financial sustainability of the initiatives. This category also includes the difficulties of remaining price competitive for low-value transactions.

- Regulation: the need for public regulation, especially to enable innovative business models in highly regulated environments.

Other restrictions and obstacles were also identified, such as: conservatism (opportunities for new services, different from traditional banking services); economic constraints; and a specific market context.

It is also worth noting that the female dimension was often discussed and highlighted, because of its important role in social development strategies.

The "results of mobile money" (initiatives, concepts, and business cases) have been discussed in non-peer reviewed articles. However, although many articles stated that "mobile money" is a reality in several contexts and countries - and usually mentioned the M-PESA case in Kenya - 
most of them still viewed "mobile money" as an opportunity or prospect for the future. In other words, despite the potential of mobile money, it will not be achieved immediately.

Mobile money has been considered to be an important MNO strategy, mainly on account of its churn reduction, but also because it offers a potential new source of revenue for the MNOs. Thus, even though mobile money is a small fraction of the total MNO revenue today, it may be a longterm opportunity if some of the profitability issues can be solved.

In addition to the obstacles and restrictions discussed earlier, the results also mentioned the following: the lack of effective marketing efforts; the profitability of the mobile money business models (including consumer pricing, cost reduction strategies for customers; financial sustainability; and the way that the services are priced and perceived by the users); liquidity factor for agents; public regulations; and the need to reach scale. For many authors, mobile money is still a very complex service, which must be simplified before it may become a useful financial service for mass users.

Whether viewed as an obstacle or an opportunity, the results show that consumer trust is an essential attribute for the adoption and effective use of mobile money services, and its construction may involve various measures from simple marketing initiatives to profound changes in business models.

\section{DISCUSSION AND CONCLUSION}

This paper has extensively analysed academic and non-academic papers related to the important topic of mobile money. After searching significant sources to identify who (researchers and institutions) is publishing what (the related topics) and where (the countries studied, journals and databases), this paper has attempted to provide a comprehensive picture of the knowledge production and dissemination of mobile for payments around the world.

By examining peer-reviewed and non-peer-reviewed papers from relevant academic and nonacademic sources, we sought for information related to mobile money and payment that could help us to understand the following dimensions: the interactions between the different actors involved in these initiatives; the factors that impeded or encouraged their adoption; the main services delivered; the effects on local flows of money; legal and regulatory environments as well as the role of authorities; and related issues of gender behaviour. 
Although a fairly extensive search was carried out on almost two hundred papers, which can be considered to be very representative of the publications on mobile money and payment, we found that little attention had been paid to the dimensions we searched for. This gap in the literature helps to explain why a service with such a huge potential has not been disseminated worldwide. This failure includes the following factors: the fact that successful cases are not clearly understood, and as a result, are not being easily replicated; the problem that obstacles and unsuccessful cases are, in most countries, not being investigated in sufficient depth to allow implementation strategies to be based on reliable business models; and the fact that the potential social and economic effects are not being assessed properly with the result that the policy makers are not convinced of the need to invest heavily in fostering favourable regulatory environments for digital payment.

At the same time, the literature review revealed the most important issues currently being investigated by specialists in the field with regard to mobile money and payment, and thus allowed us to understand the main contribution they can make to this area of study. This information can act as a starting- point for drawing up a research agenda that can be adopted by academics, policy makers and practitioners concerned with the subject of mobile payments.

Furthermore, some clear gaps in our knowledge of mobile payments were discovered by the research and analysis. Some of these gaps represent important issues that can be explored in future research in the field. Similarly to Duncombe and Boateng (2009), the present literature review confirms the same gaps pointed to by those authors (geographical, methodological and conceptual), even analyzing a more comprehensive sample. It was confirmed the existence of an important theoretical gap related to the central themes of study in the analysed articles: an expressive portion of them focuses on issues such as adoption or market analysis, neglecting other relevant themes, such as regulation and effective socio-economic impacts. Even among the studies focused on consumer adoption, there is a significant concentration on a few theories: many of them use theoretical models like TAM (Technology Acceptance Model) and its variations, aiming to identify the factors that may influence the adoption of mobile money and payment, denoting another theoretical gap.

In addition, the studies are concentrated in a few cases/countries, with emphasis on Kenya and the Philippines, although there are experiences in dozens of other countries (Beshouri et al. 2010). Thus, an important geographic gap is evidenced, because although there are emerging 
mobile money/payments initiatives worldwide, academic and non-academic production does not cover them adequately, as is the case of emerging initiatives in Latin American countries. On the peer-reviewed papers side, this situation might be attributed to the relative absence of Latin American researchers in the mainstream of academic journals, which are largely dominated by researchers from developed countries. On the other hand, the emergence of studies in Africa and Asia is a striking feature and suggests that the experiences in these countries have attracted more interest from researchers in developed countries. As other non-academic research institutions and consultancy firms have embarked on their publishing activities on this subject later than the academic institutions, the influence of such cases in Africa, for example, has become dominant. The low economic and social importance attached to mobile payment experiences in the regionsuch as the case of Daviplata, in Colombia and Paggo, in Brazil, for example - might also be related to the limited ability of banks, MNOs and regulators to understand regional peculiarities concerning mobile payment models. This situation opens up opportunities for researchers to turn their attention to this issue and carry out in-depth investigations in the region.

As an example of track research that can also be followed by researchers, current experiences of financial inclusion can point to correspondent banking networks, which had been successful in developing alternative payment channels for the poor in countries like Brazil, Colombia and Peru, for example, long before mobile payment models became a part of the international agenda (Diniz et. al. 2011; Mas 2009; Kumar et. al. 2006). Although different in many ways from one another, the correspondent and mobile payment systems require a complex web of relationships among a wide range of actors to deliver financial services to an underserved part of the population, which is at the same time supported by a strong regulatory environment. Understanding the process of building such a complex network of relationships could be helpful to mobile money researchers in at least two ways: first to encourage an analysis to be conducted of the actors' interactions that made it possible for this complex network to grow in countries in the region; and second to seek opportunities to include the use of mobile devices in the correspondent model, since it is still based on a system of cash payments, which is clearly an inefficient method that must be superseded.

Another important gap that was identified in the published literature related to mobile money is the relative absence of an analysis of the economic or social impact. Most studies, in particular non-academic ones, take social and economic impacts for granted or just give them a cursory mention, without further investigation or corroborative analysis. To improve research in this area, 
studies related to microfinance could be inspirational, since in this field the emergence of randomized studies and other techniques have led to this system being widely adopted. This follows many years of numerous superficial investigations but few in-depth research- based studies that can be used to provide evidence of the real impact of microfinance practices on alleviating poverty at micro (household), meso (community) and macro (regional or country) levels. It is understandable that the effects of these studies in social sciences are still to be felt, in view of the unsuitable conditions for carrying out experiments and isolating variables (because of the sheer number involved and the difficulty of making precise measurements) in order to make comparisons, either geographically or over a period of time. Despite the challenge, it is essential for this area of studies to be sponsored by research institutions.

Among the many questions in the area of mobile payment studies that require answers, the following should be highlighted: the typology of business models, the legal issues involved in the implementations (whether successful or unsuccessful), the kinds of technology associated with the particular business models adopted, cultural and demand conditions for a model being disseminated, an analysis of the telecommunications and banking market, obstacles to its adoption, gender issues and services. What is now apparent is a scenario that can be regarded as the dawn of an investigation into mobile money and payment. In view of the recent history of this subject-area, this can be expected. Similarly, answers to these questions must be found to ensure that mobile money and payment really takes off, as everybody involved in this market believes it is bound to happen in the near future, and money as we know it today will be largely handled by electronic devices. Moreover, this trend should be welcomed for the sake of social and economic development and to benefit the majority of the population, including the poor.

\section{REFERENCES}

BEM, Daryl J. (1995). Writing a Review Article for Psychological Bulletin, Psychological Bulletin, 1995, vol. 118, no. 2, p. 172-177.

BESHOURI, Chris; CHAIA, Alberto; COBER, Beth; GRAVRÅK, Jon (2010). Banking on mobile to deliver financial services to the poor. Global Financial Inclusion. McKinsey \& Company's Social Sector office. 
DAHLBERG, T, N MALLAT, J ONDRUS, and A ZMIJEWSKA (2008). 'Past, present and future of mobile payments research: A literature review." Electronic Commerce Research and Applications 7 (2): 165-181.

DINIZ, E.; BIROCHI, R.; POZZEBON, M. (2011) Triggers and barriers to financial inclusion: The use of ICT-based branchless banking in an Amazon county. Electronic Commerce Research and Applications, ISSN 1567-4223, 10.1016/j.elerap.2011.07.006. Available online 16/Aug/2011: http://www.sciencedirect.com/science/article/pii/S1567422311000433

DUNCOMBE, Richard; BOATENG, Richard (2009). Mobile Phones and Financial Services in Developing Countries: A Review Of Concepts, Methods, Issues, Evidence And Future Research Directions, Third World Quarterly, 30 (7): 1237-1258.

JENKINGS, Beth (2008). Developing Mobile Money Ecosystems. Washington, DC: IFC and the Harvard Kennedy School, 2008.

KUMAR, A., NAIR, A., PARSONS, A., and URDAPILLETA, E. (2006). Expanding bank outreach through 1071 retail partnerships: Correspondent banking in Brazil. World Bank Working 1072 Paper 85, Washington, DC, 2006.

LAUKKANEN, Tommi [et alii] (2008). Segmenting bank customers by resistance to mobile banking. International Journal of Mobile Communications, vol. 6, no. 3, p. 309-320, 2008.

MAS, I. (2009). The economics of branchless banking. Innovations: Technology, Governance, 1082 Globalization, 4, 2, 2009, 57-75.

SHEN, Sandy (2011). Hype Cycle for Consumer Services and Mobile Applications 2011. [Stamford]: Gartner, Inc., July 27, 2011.

SINCLAIR, James; CARDEW-HALL, Michael (2008). The folksonomy tag cloud: when is it useful? Journal of Information Science, 2008, Vol. 34 Issue 1, p15-29, 15p.

WEBSTER, Jane; WATSON, Richard T. (2002). Analyzing the Past to Prepare for the Future: Writing a Literature Review. MIS Quarterly, June 2002, vol. 26, no. 2, p. xiii- xxiii. 
ANNEX 1 - Peer-re viewed literature analysed

\begin{tabular}{|c|c|c|c|c|}
\hline$\#$ & Name & Author(s) & $\begin{array}{c}\text { Year of } \\
\text { Publication }\end{array}$ & Journal / Conference \\
\hline 1 & $\begin{array}{l}\text { Toward an understanding of the } \\
\text { behavioral intention to use mobile } \\
\text { banking }\end{array}$ & Luarn, P; Lin, H & 2005 & Computers in Human Behavior \\
\hline 2 & $\begin{array}{l}\text { The Role of Technological and Social } \\
\text { Factors on the Adoption of Mobile } \\
\text { Payment Technologies on the } \\
\text { Adoption of Mobile Pay ment } \\
\text { Technologies }\end{array}$ & $\begin{array}{l}\text { Lee, Cheon-pyo; } \\
\text { Warkentin, Merrill }\end{array}$ & 2004 & MIS Quarterly \\
\hline 3 & $\begin{array}{l}\text { Mobile Pay ment Industry : Toward a } \\
\text { Comprehensive Research Model }\end{array}$ & Amoroso, Donald L & 2010 & $\begin{array}{l}\text { Annual Conference of Japan Society for } \\
\text { Management Information } 2010 \text { Autumn }\end{array}$ \\
\hline 4 & $\begin{array}{l}\text { A comparison of mobile pay ment } \\
\text { procedures in Finnish and Chinese } \\
\text { markets }\end{array}$ & Zhong, Junying & 2009 & $\begin{array}{l}\text { Proceeding of the 22nd Bled eConference } \\
\text { eEnablement }\end{array}$ \\
\hline 5 & $\begin{array}{l}\text { Information capability and value } \\
\text { creation strategy: advancing revenue } \\
\text { management through mobile ticketing } \\
\text { technologies }\end{array}$ & $\begin{array}{l}\text { Li, Ting; van Heck, } \\
\text { Eric; Vervest, Peter }\end{array}$ & 2009 & European Journal of Information Systems \\
\hline 6 & $\begin{array}{l}\text { Customer Satisfaction with Cell } \\
\text { Phone Banking in South Africa }\end{array}$ & $\begin{array}{l}\text { Brown, Irwin; Licker, } \\
\text { Paul }\end{array}$ & 2010 & AMCIS 2010 Proceedings \\
\hline 7 & $\begin{array}{l}\text { Evaluating the Role of Trust in } \\
\text { Consumer Adoption of Mobile } \\
\text { Payment Systems: An Empirical } \\
\text { Analy sis }\end{array}$ & $\begin{array}{l}\text { Chandra, Shalini; } \\
\text { Srivastava, S.C.; } \\
\text { Theng, Y.L. }\end{array}$ & 2010 & $\begin{array}{l}\text { Communications of the Association for } \\
\text { Information Systems }\end{array}$ \\
\hline 8 & $\begin{array}{l}\text { Exploring consumer adoption of } \\
\text { mobile pay ments - A qualitative } \\
\text { study }\end{array}$ & Mallat, N & 2007 & $\begin{array}{l}\text { The Journal of Strategic Information } \\
\text { Systems }\end{array}$ \\
\hline 9 & $\begin{array}{l}\text { Why Mobile Payments Fail ? } \\
\text { Towards a Dy namic and Multi- } \\
\text { perspective Explanation }\end{array}$ & $\begin{array}{l}\text { Ondrus, Jan; } \\
\text { Lyytinen, Kalle; } \\
\text { Pigneur, Yves }\end{array}$ & 2009 & $\begin{array}{l}\text { 42nd Hawaii International Conference on } \\
\text { System Sciences }\end{array}$ \\
\hline 10 & $\begin{array}{l}\text { Incorporating M-Commerce into } \\
\text { Organizational Strategy: A Case } \\
\text { Study in the Tourism Sector }\end{array}$ & $\begin{array}{l}\text { Srivastra, A.; } \\
\text { Tassabehji, Rana; } \\
\text { Wallace, D.J. }\end{array}$ & 2007 & AMCIS 2007 Proceedings \\
\hline 11 & $\begin{array}{l}\text { Intention to Use Mobile Commerce: } \\
\text { A Demographic Analy sis of the } \\
\text { Chinese Market }\end{array}$ & $\begin{array}{l}\text { Dai, Hua; Singh, } \\
\text { Rahul; Iyer, Lakshmi }\end{array}$ & 2007 & AMCIS 2007 Proceedings \\
\hline 12 & $\begin{array}{l}\text { Agent enabled composition of } \\
\text { Services Bundles for M-Commerce } \\
\text { Applications }\end{array}$ & Leary, Thomas & 2004 & AMCIS 2004 Proceedings \\
\hline 13 & $\begin{array}{l}\text { A Risk Assessment Framework for } \\
\text { Mobile Payments }\end{array}$ & Clark, Roger & 2008 & BLED 2008 Proceedings \\
\hline 14 & $\begin{array}{l}\text { Lost Opportunity Why Has Dominant } \\
\text { Design Failed to Emerge for the } \\
\text { Mobile Pay ment Services Market in } \\
\text { Finland? }\end{array}$ & $\begin{array}{l}\text { Dahlberg, Tomi; } \\
\text { Huurros, Milla; } \\
\text { Ainamo, Antti }\end{array}$ & 2008 & $\begin{array}{l}\text { Proceedings of the } 41 \text { st Annual Hawaii } \\
\text { International Conference on Sy stem } \\
\text { Sciences (HICSS 2008) }\end{array}$ \\
\hline 15 & $\begin{array}{l}\text { Understanding changes in consumer } \\
\text { payment habits-do mobile payments } \\
\text { and electronic invoices attract } \\
\text { consumers? }\end{array}$ & $\begin{array}{l}\text { Dahlberg, Tomi; } \\
\text { Oorni, A. }\end{array}$ & 2007 & $\begin{array}{l}\text { Sy stem Sciences, 2007. HICSS } 2007 . \\
\text { 40th Annual Hawaii International } \\
\text { Conference on }\end{array}$ \\
\hline 16 & $\begin{array}{l}\text { The industry chain of mobile payment } \\
\text { and its future development mode }\end{array}$ & $\begin{array}{l}\text { Zexi, A.; Xuecheng, } \\
\text { Y.; Tong, W. }\end{array}$ & 2010 & $\begin{array}{l}\text { Communication Systems, Networks and } \\
\text { Applications (ICCSNA), } 2010 \text { Second } \\
\text { International Conference on }\end{array}$ \\
\hline 17 & $\begin{array}{l}\text { The Importance of Trust and Risk in } \\
\text { M-Commerce: A South African } \\
\text { Perspective }\end{array}$ & $\begin{array}{l}\text { Joubert, Janine; Van } \\
\text { Belle, J.P. }\end{array}$ & 2009 & $\begin{array}{l}\text { Pacific Asia Conference on Information } \\
\text { Systems }\end{array}$ \\
\hline 18 & $\begin{array}{l}\text { Current mobile payment procedures } \\
\text { on the German market from the view } \\
\text { of customer requirements }\end{array}$ & $\begin{array}{l}\text { Pousttchi, K.; Zenker, } \\
\text { M. }\end{array}$ & 2003 & $\begin{array}{l}\text { 14th International Workshop on Database } \\
\text { and Expert Sy stems Applications, } 2003 . \\
\text { Proceedings. }\end{array}$ \\
\hline
\end{tabular}




\begin{tabular}{|c|c|c|c|c|}
\hline 19 & $\begin{array}{l}\text { Merchant Adoption of Mobile } \\
\text { Payment Systems }\end{array}$ & $\begin{array}{l}\text { Mallat, N.; } \\
\text { Tuunainen, V.K. }\end{array}$ & 2005 & $\begin{array}{l}\text { International Conference on Mobile } \\
\text { Business (ICMB'05) }\end{array}$ \\
\hline 20 & $\begin{array}{l}\text { An Exploratory Study of Information } \\
\text { Sy stems Resistance : The Case of } \\
\text { Mobile Banking Sy stems in Korea } \\
\text { and Finland }\end{array}$ & $\begin{array}{l}\text { Lee, Cheon-pyo; } \\
\text { Mattila, Minna; Shim, } \\
\text { J P }\end{array}$ & 2007 & AMCIS 2007 Proceedings \\
\hline 21 & $\begin{array}{l}\text { Empirical research of mobile } \\
\text { payment user behavior based on } \\
\text { perceived risk }\end{array}$ & $\begin{array}{l}\text { Xianfeng, Wu; } \\
\text { Jihong, F. }\end{array}$ & 2010 & $\begin{array}{l}\text { Communication Sy stems, Networks and } \\
\text { Applications (ICCSNA), } 2010 \text { Second } \\
\text { International Conference on }\end{array}$ \\
\hline 22 & $\begin{array}{l}\text { User Acceptance Testing of Mobile } \\
\text { Payment in Various Scenarios }\end{array}$ & $\begin{array}{l}\text { Ho, Henry; Fong, } \\
\text { Simon; Yan, Zhuang }\end{array}$ & 2008 & $\begin{array}{l}2008 \text { IEEE International Conference on e- } \\
\text { Business Engineering }\end{array}$ \\
\hline 23 & $\begin{array}{l}\text { Research on Mobile Payment in the } \\
\text { E-Commerce }\end{array}$ & $\begin{array}{l}\text { Li, Yunhong; Luo, } \\
\text { Siwen }\end{array}$ & 2008 & $\begin{array}{l}2008 \text { International Conference on } \\
\text { Management of e-Commerce and e- } \\
\text { Government }\end{array}$ \\
\hline 24 & $\begin{array}{l}\text { A Proposal for a Multi-Perspective } \\
\text { Analy sis of the Mobile Payment } \\
\text { Environment }\end{array}$ & $\begin{array}{l}\text { Ondrus, J.; } \\
\text { Camponovo, G.; } \\
\text { Pigneur, Y. }\end{array}$ & 2005 & $\begin{array}{l}\text { International Conference on Mobile } \\
\text { Business (ICMB'05) }\end{array}$ \\
\hline 25 & $\begin{array}{l}\text { Analy zing the Elements of the } \\
\text { Business Model for Mobile Pay ment } \\
\text { Service Provision }\end{array}$ & $\begin{array}{l}\text { Pousttchi, Key; } \\
\text { Schiessler, Max; } \\
\text { Wiedemann, Dietmar } \\
\text { G. }\end{array}$ & 2007 & $\begin{array}{l}\text { International Conference on the } \\
\text { Management of Mobile Business (ICMB } \\
\text { 2007) }\end{array}$ \\
\hline 26 & $\begin{array}{l}\text { Mobile Payment Applications: An } \\
\text { Exploratory Analysis of the Italian } \\
\text { Diffusion Process }\end{array}$ & $\begin{array}{l}\text { Balocco, Raffaello; } \\
\text { Ghezzi, Antonio; } \\
\text { Bonometti, Giuseppe; } \\
\text { Renga, Filippo }\end{array}$ & 2008 & $\begin{array}{l}2008 \text { 7th International Conference on } \\
\text { Mobile Business }\end{array}$ \\
\hline 27 & $\begin{array}{l}\text { A Study of Mobile Payment Mode in } \\
\text { U-Commerce }\end{array}$ & Qiang, Yan; Lu, T. & 2008 & $\begin{array}{l}\text { Wireless Communications, Networking } \\
\text { and Mobile Computing, } 2008 . \\
\text { WiCOM'08. 4th International Conference } \\
\text { on }\end{array}$ \\
\hline 28 & $\begin{array}{l}\text { A study of major Mobile payment } \\
\text { systems' functionality in Europe }\end{array}$ & $\begin{array}{l}\text { Mohammadi, } \\
\text { Shahriy ar; } \\
\text { Jahanshahi, Hediye }\end{array}$ & 2008 & $\begin{array}{l}2008 \text { 11th International Conference on } \\
\text { Computer and Information Technology }\end{array}$ \\
\hline 29 & $\begin{array}{l}\text { Research on the Influence of Mobile } \\
\text { Payment and Its Industry Chain on } \\
\text { Customer Value }\end{array}$ & Lu, Xiang; Shu, H. & 2009 & $\begin{array}{l}\text { Management and Service Science, } 2009 . \\
\text { MASS'09. International Conference on }\end{array}$ \\
\hline 30 & $\begin{array}{l}\text { Mobile pay ment: A journey through } \\
\text { existing procedures and } \\
\text { standardization initiatives }\end{array}$ & Karnouskos, S.; & 2004 & $\begin{array}{l}\text { Communications Surveys \& Tutorials, } \\
\text { IEEE }\end{array}$ \\
\hline 31 & $\begin{array}{l}\text { Consumer acceptance of mobile } \\
\text { payments: An empirical study }\end{array}$ & Suhuai, L.; Peter, S. & 2010 & $\begin{array}{l}\text { New Trends in Information Science and } \\
\text { Service Science (NISS), 2010 4th } \\
\text { International Conference on }\end{array}$ \\
\hline 32 & $\begin{array}{l}\text { Mobile Payment: An Exploratory } \\
\text { Study of Customer Attitudes }\end{array}$ & $\begin{array}{l}\text { Petrova, Krassie; } \\
\text { Mehra, Ridhima }\end{array}$ & 2010 & $\begin{array}{l}2010 \text { 6th International Conference on } \\
\text { Wireless and Mobile Communications }\end{array}$ \\
\hline 33 & $\begin{array}{l}\text { Are Mobile Payment and Banking the } \\
\text { Killer Apps for Mobile Commerce? }\end{array}$ & $\begin{array}{l}\text { Hu, Xianpei; Li, } \\
\text { Wenli; Hu, Qing }\end{array}$ & 2008 & $\begin{array}{l}\text { Proceedings of the 41st Annual Hawaii } \\
\text { International Conference on Sy stem } \\
\text { Sciences (HICSS 2008) }\end{array}$ \\
\hline 34 & Study of Mobile Payments Sy stem & Zheng, Xiaolin & 2003 & $\begin{array}{l}\text { Proceedings of the IEEE International } \\
\text { Conference on E-Commerce (CEC'03) }\end{array}$ \\
\hline 35 & Issues in Mobile E-Commerce & $\begin{array}{l}\text { Tarasewich, Peter; } \\
\text { Nickerson, R.C.; } \\
\text { Warkentin, Merrill }\end{array}$ & 2002 & $\begin{array}{l}\text { Communications of the Association for } \\
\text { Information Systems (Volume } 8,2002 \text { ) }\end{array}$ \\
\hline 36 & $\begin{array}{l}\text { M-PESA: Mobile Money for the } \\
\text { "Unbanked" Turning Cellphones into } \\
\text { 24-Hour Tellers in Keny a }\end{array}$ & $\begin{array}{l}\text { Hughes, Nick; Lonie, } \\
\text { Susie }\end{array}$ & 2007 & $\begin{array}{l}\text { Innovations: Technology, Governance, } \\
\text { Globalization }\end{array}$ \\
\hline 37 & $\begin{array}{l}\text { The failure of mobile payment: } \\
\text { evidence from quasi- } \\
\text { experimentations }\end{array}$ & Rouibah, Kamel & 2009 & $\begin{array}{l}\text { Proceedings of the } 2009 \text { Euro American } \\
\text { Conference on Telematics and } \\
\text { Information Sy stems: New Opportunities } \\
\text { to increase Digital Citizenship }\end{array}$ \\
\hline 38 & $\begin{array}{l}\text { Mobile Money Transfer Services: } \\
\text { The Next Phase in the Evolution in } \\
\text { Person-to-Person Payments }\end{array}$ & Merritt, Cynthia & 2010 & Retail Payments Risk Forum \\
\hline
\end{tabular}




\begin{tabular}{|c|c|c|c|c|}
\hline 39 & $\begin{array}{l}\text { Comparative Study on M-Commerce } \\
\text { Applications in Various Scenarios }\end{array}$ & $\begin{array}{l}\text { Fong, Simon; Yan, } \\
\text { Zhuang }\end{array}$ & 2008 & $\begin{array}{l}2008 \text { IEEE/WIC/ACM International } \\
\text { Conference on Web Intelligence and } \\
\text { Intelligent Agent Technology }\end{array}$ \\
\hline 40 & $\begin{array}{l}\text { A Scenario-Based Analysis of Mobile } \\
\text { Payment Acceptance }\end{array}$ & $\begin{array}{l}\text { Goeke, Laura; } \\
\text { Pousttchi, Key }\end{array}$ & 2010 & $\begin{array}{l}2010 \text { Ninth International Conference on } \\
\text { Mobile Business and } 2010 \text { Ninth Global } \\
\text { Mobility Roundtable (ICMB-GMR) }\end{array}$ \\
\hline 41 & $\begin{array}{l}\text { A study on the success potential of } \\
\text { multiple mobile payment } \\
\text { technologies }\end{array}$ & $\begin{array}{l}\text { Mathew, Mary; } \\
\text { Balakrishnan, N.; } \\
\text { Pratheeba, S. }\end{array}$ & 2010 & $\begin{array}{l}\text { Technology Management for Global } \\
\text { Economic Growth (PICMET), } 2010 \\
\text { Proceedings of PICMET'10: }\end{array}$ \\
\hline 42 & $\begin{array}{l}\text { Developing an Analytical Framework } \\
\text { for Mobile Payments Adoption in } \\
\text { Retailing: A Supply-Side Perspective }\end{array}$ & $\begin{array}{l}\text { Lai, P.M.; Chuah, } \\
\text { K.B. }\end{array}$ & 2010 & $\begin{array}{l}2010 \text { International Conference on } \\
\text { Management of e-Commerce and e- } \\
\text { Government }\end{array}$ \\
\hline 43 & Mobile banking services & $\begin{array}{l}\text { Mallat, Niina; Rossi, } \\
\text { Matti; Tuunainen, } \\
\text { Virpi Kristiina }\end{array}$ & 2004 & Communications of the ACM \\
\hline 44 & Mobile commerce at crossroads & $\begin{array}{l}\text { Jarvenpaa, S.L.; Lang, } \\
\text { K.R.; Takeda, Y. } \\
\text { Tuunainen, V.K. }\end{array}$ & 2003 & Communications of the ACM \\
\hline 45 & $\begin{array}{l}\text { Ranking secure technologies in } \\
\text { security provision financial } \\
\text { transactions mobile commerce }\end{array}$ & $\begin{array}{l}\text { Saghafi, Fatemeh; } \\
\text { NasserEslami, } \\
\text { Fatemeh; Esmaili, } \\
\text { Mary am }\end{array}$ & 2009 & $\begin{array}{l}\text { Proceedings of the 2nd International } \\
\text { Conference on Interaction Sciences } \\
\text { Information Technology, Culture and } \\
\text { Human - ICIS '09 }\end{array}$ \\
\hline 46 & $\begin{array}{l}\text { Study on consumer demands and } \\
\text { merchant participation motives of } \\
\text { mobile payment services in China }\end{array}$ & $\begin{array}{l}\text { Xiny an, Zhao; Wei, } \\
\text { Ge; Tingie, Lu }\end{array}$ & 2009 & $\begin{array}{l}\text { Proceedings of the 2nd International } \\
\text { Conference on Interaction Sciences } \\
\text { Information Technology, Culture and } \\
\text { Human - ICIS '09 }\end{array}$ \\
\hline 47 & $\begin{array}{l}\text { Mobile commerce adoption in China } \\
\text { and the United States: a cross-cultural } \\
\text { study }\end{array}$ & Dai, Hua; Palvi, P.C. & 2009 & ACM SIGMIS Database \\
\hline 48 & $\begin{array}{l}\text { Mobile Payments at the Retail Point } \\
\text { of Sale in the United States: Prospects } \\
\text { for Adoption }\end{array}$ & $\begin{array}{l}\text { Crowe, Marianne; } \\
\text { Ry sman, Marc; } \\
\text { Stavins, Joanna }\end{array}$ & 2010 & Review of Network Economics \\
\hline 49 & $\begin{array}{l}\text { An empirical examination of factors } \\
\text { influencing the intention to use } \\
\text { mobile payment }\end{array}$ & $\begin{array}{l}\text { Kim, Changsu; } \\
\text { Mirusmonov, } \\
\text { Mirsobit; Lee, In }\end{array}$ & 2010 & Computers in Human Behavior \\
\hline 50 & $\begin{array}{l}\text { Inter-consortia battles in mobile } \\
\text { payments standardisation }\end{array}$ & Lim, a & 2008 & $\begin{array}{l}\text { Electronic Commerce Research and } \\
\text { Applications }\end{array}$ \\
\hline 51 & $\begin{array}{l}\text { A modeling approach and reference } \\
\text { models for the analy sis of mobile } \\
\text { payment use cases }\end{array}$ & Pousttchi, K & 2008 & $\begin{array}{l}\text { Electronic Commerce Research and } \\
\text { Applications }\end{array}$ \\
\hline 52 & $\begin{array}{l}\text { A Game Analy sis of the Relationship } \\
\text { among Government, Mobile Operator } \\
\text { and Finance Organization in China } \\
\text { Mobile Pay ment Industry Chain }\end{array}$ & $\begin{array}{l}\text { Ou, Haiying; Lv, } \\
\text { Tingjie; Chen, Xia }\end{array}$ & 2009 & $\begin{array}{l}2009 \text { International Conference on } \\
\text { Business Intelligence and Financial } \\
\text { Engineering }\end{array}$ \\
\hline 53 & $\begin{array}{l}\text { Towards a holistic analy sis of mobile } \\
\text { pay ments: A multiple perspectives } \\
\text { approach }\end{array}$ & Ondrus, J; Pigneur, Y & 2006 & $\begin{array}{l}\text { Electronic Commerce Research and } \\
\text { Applications }\end{array}$ \\
\hline 54 & $\begin{array}{l}\text { Understanding consumer acceptance } \\
\text { of mobile pay ment services: An } \\
\text { empirical analy sis }\end{array}$ & $\begin{array}{l}\text { Schierz, Paul } \\
\text { Gerhardt; Schilke, } \\
\text { Oliver; Wirtz, Bernd } \\
\text { W. }\end{array}$ & 2010 & $\begin{array}{l}\text { Electronic Commerce Research and } \\
\text { Applications }\end{array}$ \\
\hline 55 & $\begin{array}{l}\text { Towards an understanding of the } \\
\text { consumer acceptance of mobile } \\
\text { wallet }\end{array}$ & Shin, Dong-Hee & 2009 & Computers in Human Behavior \\
\hline 56 & $\begin{array}{l}\text { Mobile Payment Procedures: Scope } \\
\text { and Characteristics }\end{array}$ & $\begin{array}{l}\text { Kreyer, Nina; } \\
\text { Pousttchi, Key; } \\
\text { Turowski, Klaus }\end{array}$ & 2003 & e-Service Journal \\
\hline 57 & $\begin{array}{l}\text { Standardized payment procedures as } \\
\text { key enabling factor for mobile } \\
\text { commerce }\end{array}$ & $\begin{array}{l}\text { Kreyer, N.; Pousttchi, } \\
\text { K.; Turowski, K. }\end{array}$ & 2002 & E-Commerce and Web Technologies \\
\hline 58 & $\begin{array}{l}\text { A model of consumer acceptance of } \\
\text { mobile payment }\end{array}$ & Chen, Lei Da & 2008 & $\begin{array}{l}\text { International Journal of Mobile } \\
\text { Communications }\end{array}$ \\
\hline
\end{tabular}




\begin{tabular}{|c|c|c|c|c|}
\hline 59 & $\begin{array}{l}\text { Mobile banking services in the bank } \\
\text { area }\end{array}$ & $\begin{array}{l}\text { Shirali-Shahreza, } \\
\text { Mohammad; Shirali- } \\
\text { Shahreza, M. Hassan }\end{array}$ & 2007 & SICE Annual Conference 2007 \\
\hline 60 & $\begin{array}{l}\text { Diffusion of Mobile Commerce } \\
\text { Application in the Market }\end{array}$ & $\begin{array}{l}\text { Huang, Hao; Liu, Lu; } \\
\text { Wang, Jianjun }\end{array}$ & 2007 & $\begin{array}{l}\text { Second International Conference on } \\
\text { Innovative Computing, Informatio and } \\
\text { Control (ICICIC 2007) }\end{array}$ \\
\hline 61 & $\begin{array}{l}\text { Factors influencing the adoption } \\
\text { behavior of mobile banking: a South } \\
\text { Korean perspective }\end{array}$ & Lee, KS; Lee, HS & 2007 & $\begin{array}{l}\text { Journal of Internet Banking and } \\
\text { Commerce }\end{array}$ \\
\hline 62 & $\begin{array}{l}\text { A Contextual Acceptance Model of } \\
\text { Mobile Commerce B ased on TAM }\end{array}$ & $\begin{array}{l}\text { Xu, Zhengchuan; } \\
\text { Zhang, Chen ghong; } \\
\text { Ling, Hong }\end{array}$ & 2008 & $\begin{array}{l}2008 \text { The Third International Multi- } \\
\text { Conference on Computing in the Global } \\
\text { Information Technology (iccgi 2008) }\end{array}$ \\
\hline 63 & $\begin{array}{l}\text { Design and Evaluation of M- } \\
\text { Commerce Applications }\end{array}$ & $\begin{array}{l}\text { Wang, J.J.; Song, Z.; } \\
\text { Lei, P.; Sheriff, R.E. }\end{array}$ & 2005 & $\begin{array}{l}2005 \text { Asia-Pacific Conference on } \\
\text { Communications }\end{array}$ \\
\hline 64 & $\begin{array}{l}\text { Study on Trust in Mobile Commerce } \\
\text { Adoption - A Conceptual Model }\end{array}$ & $\begin{array}{l}\text { Meng, Decai; Min, } \\
\text { Qingfei; Li, Yuping }\end{array}$ & 2008 & $\begin{array}{l}2008 \text { International Sy mposium on } \\
\text { Electronic Commerce and Security }\end{array}$ \\
\hline 65 & $\begin{array}{l}\text { Assessing the Mobile Banking } \\
\text { Adoption Based on the Decomposed } \\
\text { Theory of Planned Behaviour }\end{array}$ & $\begin{array}{l}\text { Beiginia, A.R.; } \\
\text { Besheli, A.S.; } \\
\text { Soluklu, M.E.; } \\
\text { Ahmadi, M. }\end{array}$ & 2011 & $\begin{array}{l}\text { European Journal of Economics, Finance } \\
\text { and Administrative Sciences }\end{array}$ \\
\hline 66 & $\begin{array}{l}\text { What is the Influence of Context and } \\
\text { Incentive on Mobile Commerce } \\
\text { Adoption? A Case study of a GPS- } \\
\text { based Taxi Dispatching System }\end{array}$ & $\begin{array}{l}\text { Xu, Zhengchuan; } \\
\text { Yuan, Yufei }\end{array}$ & 2007 & $\begin{array}{l}\text { International Conference on the } \\
\text { Management of Mobile Business (ICMB } \\
\text { 2007) }\end{array}$ \\
\hline 67 & $\begin{array}{l}\text { Innovations to M ake M arkets More } \\
\text { Inclusive for the Poor }\end{array}$ & $\begin{array}{l}\text { Mendoza, Ronald U.; } \\
\text { Thelen, Nina }\end{array}$ & 2008 & Development Policy Review \\
\hline 68 & $\begin{array}{l}\text { Mobile banking and economic } \\
\text { development: Linking adoption, } \\
\text { impact, and use }\end{array}$ & Donner, J.; Tellez, C. & 2008 & Asian Journal of Communication \\
\hline 69 & $\begin{array}{l}\text { M-Commerce implementation in } \\
\text { Nigeria: Trends and issues }\end{array}$ & $\begin{array}{l}\text { Ayo, CK; Ekong, UO; } \\
\text { Fatudimu, IT; } \\
\text { Adebiyi, AA }\end{array}$ & 2007 & $\begin{array}{l}\text { Journal of Internet Banking and } \\
\text { Commerce }\end{array}$ \\
\hline 70 & $\begin{array}{l}\text { M-Pesa: A Case Study of the Critical } \\
\text { Early Adopters's Role in the Rapid } \\
\text { Adoption of Mobile Money Banking } \\
\text { in Keny a }\end{array}$ & $\begin{array}{l}\text { KGUGI, Benjamin; } \\
\text { PELOWSKI, } \\
\text { Matthew; OGEMBO, } \\
\text { Javier G. }\end{array}$ & 2010 & $\begin{array}{l}\text { The Electronic Journal of Information } \\
\text { Systems in Developing Countries }\end{array}$ \\
\hline 71 & $\begin{array}{l}\text { Mobile 2.0: M-money for the } \mathrm{BoP} \text { in } \\
\text { the Philippines }\end{array}$ & $\begin{array}{l}\text { ALAMPAY, Erwin; } \\
\text { BALA, Gemma. }\end{array}$ & 2010 & $\begin{array}{l}\text { Information Technologies \& International } \\
\text { Development }\end{array}$ \\
\hline 72 & $\begin{array}{l}\text { ICT, Development and Povery } \\
\text { Reduction: Five Emerging Stories }\end{array}$ & $\begin{array}{l}\text { SPENCE, Randy; } \\
\text { SMITH, Matthew L. }\end{array}$ & 2010 & $\begin{array}{l}\text { Information Technologies \& International } \\
\text { Development }\end{array}$ \\
\hline 73 & $\begin{array}{l}\text { Adopting mobile pay ment channels: } \\
\text { Key challen ges for US fin ancial } \\
\text { institutions }\end{array}$ & $\begin{array}{l}\text { KAPOSTASY, Janet } \\
\text { L. }\end{array}$ & 2008 & Journal of Pay ments Strategy \& Sy stems \\
\hline 74 & $\begin{array}{l}\text { The Enigma of Mobile Money } \\
\text { Systems }\end{array}$ & $\begin{array}{l}\text { Ernesto M. FLORES- } \\
\text { ROUX \& Judith } \\
\text { MARISCAL }\end{array}$ & 2010 & COMMUNICATIONS \& STRATEGIES \\
\hline 75 & $\begin{array}{l}\text { Mobile Money: Implications for } \\
\text { Emerging Markets }\end{array}$ & $\begin{array}{l}\text { ALLEM AN, J.: } \\
\text { RAPPOPORT, P. }\end{array}$ & 2010 & COMMUNICATIONS \& STRATEGIES \\
\hline 76 & $\begin{array}{l}\text { The role of payment sy stems in } \\
\text { reaching the unbanked }\end{array}$ & Sergio de Sousa & 2010 & Journal of Payments Strategy \& Sy stems \\
\hline 77 & $\begin{array}{l}\text { Mobile Phones and Financial } \\
\text { Services in Developing Countries: a } \\
\text { review of concepts, methods, issues, } \\
\text { evidence and future research } \\
\text { directions }\end{array}$ & $\begin{array}{l}\text { Richard } \\
\text { Duncombe;Richard } \\
\text { Boateng }\end{array}$ & 2009 & Third World Quarterly \\
\hline 78 & $\begin{array}{l}\text { Framing M4D: The Utility of } \\
\text { Continuity and the Dual Heritage of" } \\
\text { Mobiles and Development" }\end{array}$ & Donner, Jonathan & 2010 & $\begin{array}{l}\text { The Electronic Journal of Information } \\
\text { Systems in Developing Countries }\end{array}$ \\
\hline 79 & $\begin{array}{l}\text { Innovative Payment Solutions in } \\
\text { Agricultural Value Chain as a Means } \\
\text { for Greater Financial Inclusion }\end{array}$ & $\begin{array}{l}\text { Tushar } \\
\text { Pandey;Nagahari } \\
\text { Krishna;Venetia } \\
\text { Vickers }\end{array}$ & 2010 & Agricultural Economics Research Review \\
\hline
\end{tabular}




\begin{tabular}{|c|c|c|c|c|}
\hline 80 & $\begin{array}{l}\text { A Financial Analy sis of Mobile } \\
\text { Money Services }\end{array}$ & Peter LYONS & 2010 & Communications \& strategies \\
\hline 81 & $\begin{array}{l}\text { Mobile Pay ments: Moving Towards a } \\
\text { Wallet in the Cloud? }\end{array}$ & $\begin{array}{l}\text { Sophie PERNET- } \\
\text { LUBRANO }\end{array}$ & 2010 & Communications \& strategies \\
\hline 82 & $\begin{array}{l}\text { Prelimin ary Insights into M - } \\
\text { commerce Adoption in Ghana }\end{array}$ & $\begin{array}{l}\text { Raymond A. Boadi, } \\
\text { Richard Boateng, } \\
\text { Robert Hinson and } \\
\text { Robert A. Opoku }\end{array}$ & 2007 & Information Development \\
\hline 83 & $\begin{array}{l}\text { From Microfinance to m-Finance } \\
\text { Innovations Case Discussion: M- } \\
\text { PESA }\end{array}$ & $\begin{array}{l}\text { Mudit } \\
\text { Kapoor;Jonathan } \\
\text { Morduch;Shamika } \\
\text { Ravi }\end{array}$ & 2007 & $\begin{array}{l}\text { Innovations: Technology, Governance, } \\
\text { Globalization }\end{array}$ \\
\hline 84 & $\begin{array}{l}\text { Cell phones, electronic delivery } \\
\text { systems and social cash transfers : } \\
\text { Recent evidence and experiences } \\
\text { from Africa }\end{array}$ & $\begin{array}{l}\text { Katharine } \\
\text { Vincent;Tracy Cull }\end{array}$ & 2011 & International Social Security Review \\
\hline 85 & $\begin{array}{l}\text { Cooperation for Innovation in } \\
\text { Payment Systems: The Case of } \\
\text { Mobile Payments }\end{array}$ & $\begin{array}{l}\text { Marc } \\
\text { Bourreau;M arianne } \\
\text { Verdier }\end{array}$ & 2010 & Communications \& strategies \\
\hline 86 & $\begin{array}{l}\text { Who will be the winners and losers in } \\
\text { the battle for mobile payments market } \\
\text { share? }\end{array}$ & Olivier Cognet & 2011 & Journal of Payments Strategy \& Sy stems \\
\hline 87 & $\begin{array}{l}\text { Three keys to M-PESA's success : } \\
\text { Branding, channel management and } \\
\text { pricing }\end{array}$ & $\begin{array}{l}\text { Ignacio Mas;Amolo } \\
\mathrm{Ng}\end{array}$ & 2011 & Journal of Payments Strategy \& Sy stems \\
\hline 88 & $\begin{array}{l}\text { Mobile Opportunities, Mobile } \\
\text { Problems: Assessing Mobile } \\
\text { Commerce Implementation Issues in } \\
\text { Malawi }\end{array}$ & E. Saidi & 2009 & $\begin{array}{l}\text { Journal of Internet Banking and } \\
\text { Commerce }\end{array}$ \\
\hline 89 & $\begin{array}{l}\text { Mobile communications and treasury } \\
\text { management - making mobile money } \\
\text { work for the business }\end{array}$ & Morten Hofstad & 2010 & $\begin{array}{l}\text { Journal of Corporate Treasury } \\
\text { Management }\end{array}$ \\
\hline 90 & Legal issues in mobile banking & $\begin{array}{l}\text { Rolf H. Weber;Aline } \\
\text { Darbellay }\end{array}$ & 2010 & Journal of Banking Regulation \\
\hline 91 & $\begin{array}{l}\text { How Mobile Money Can Drive } \\
\text { Financial Inclusion for Women at the } \\
\text { Bottom of the Pyramid (BOP) in } \\
\text { Indian Urban Centers }\end{array}$ & $\begin{array}{l}\text { A. L. Chavan;Sarit } \\
\text { Arora;Anand } \\
\text { Kumar;Praneet } \\
\text { Koppula }\end{array}$ & 2009 & $\begin{array}{l}\text { Internationalization, Design and Global } \\
\text { Development: Third International } \\
\text { Conference, IDGD 2009, Held as Part of } \\
\text { HCI International 2009, San Diego, CA, } \\
\text { USA, July 19-24, 2009, Proceedings }\end{array}$ \\
\hline 92 & $\begin{array}{l}\text { Mobile-banking adoption and usage } \\
\text { by low-literate, low-income users in } \\
\text { the developing world }\end{array}$ & $\begin{array}{l}\text { Indrani } \\
\text { Medhi;Aishwary a } \\
\text { Ratan;Kentaro } \\
\text { Toy ama }\end{array}$ & 2009 & $\begin{array}{l}\text { Internationalization, Design and Global } \\
\text { Development: Third International } \\
\text { Conference, IDGD 2009, Held as Part of } \\
\text { HCI International 2009, San Diego, CA, } \\
\text { USA, July 19-24, 2009, Proceedings }\end{array}$ \\
\hline 93 & $\begin{array}{l}\text { Mobile remittances: design for } \\
\text { financial inclusion }\end{array}$ & Supriy a Singh & 2009 & $\begin{array}{l}\text { Internationalization, Design and Global } \\
\text { Development: Third International } \\
\text { Conference, IDGD 2009, Held as Part of } \\
\text { HCI International 2009, San Diego, CA, } \\
\text { USA, July 19-24, 2009, Proceedings }\end{array}$ \\
\hline 94 & $\begin{array}{l}\text { Examining the usage and impact of } \\
\text { transformational } \mathrm{M} \text {-banking in Kenya }\end{array}$ & Olga Morawczynski & 2009 & $\begin{array}{l}\text { Internationalization, Design and Global } \\
\text { Development: Third International } \\
\text { Conference, IDGD 2009, Held as Part of } \\
\text { HCI International 2009, San Diego, CA, } \\
\text { USA, July 19-24, 2009, Proceedings }\end{array}$ \\
\hline
\end{tabular}


ANNEX 2 - Non-peer-reviewed literature analysed

\begin{tabular}{|c|c|c|c|c|}
\hline$\#$ & Title & Author(s) & Source & $\begin{array}{c}\text { Year of } \\
\text { Publication }\end{array}$ \\
\hline 1 & The alternatives to mobile money & Goss, Salah & $\begin{array}{l}\text { CGAP - Consultative } \\
\text { Group to Assist the Poor }\end{array}$ & 2011 \\
\hline 2 & Branchless Banking in South Africa & Bold, Chris & $\begin{array}{l}\text { CGAP - Consultative } \\
\text { Group to Assist the Poor }\end{array}$ & 2011 \\
\hline 3 & $\begin{array}{l}\text { A new year's resolution for the mobile } \\
\text { money industry: interoperating }\end{array}$ & Mas, Ignacio & $\begin{array}{l}\text { CGAP - Consultative } \\
\text { Group to Assist the Poor }\end{array}$ & 2011 \\
\hline 4 & $\begin{array}{l}\text { Why distributing mobile money is harder than } \\
\text { airtime for MNOs }\end{array}$ & $\begin{array}{l}\text { McKay, Claudia and } \\
\text { Pickens, Mark }\end{array}$ & $\begin{array}{l}\text { CGAP - Consultative } \\
\text { Group to Assist the Poor }\end{array}$ & 2011 \\
\hline 5 & $\begin{array}{l}\text { How mobile money is chan ging Africa: Interview } \\
\text { with Barry Coetzee of Iveri }\end{array}$ & & Mobithinking & 2011 \\
\hline 6 & Will mobile money take off in India? & & Reuters & 2011 \\
\hline 7 & $\begin{array}{l}\text { Showcasing Successes in Banking Bey ond } \\
\text { Branches: Latin American Banks Lead the Way }\end{array}$ & $\begin{array}{l}\text { Almazán, Mirey a and } \\
\text { Mas, Ignacio }\end{array}$ & $\begin{array}{l}\text { CGAP - Consultative } \\
\text { Group to Assist the Poor }\end{array}$ & 2011 \\
\hline 8 & $\begin{array}{l}\text { Haiti: Could mobile banking be a legacy of the } \\
\text { earthquake? }\end{array}$ & Bold, Chris & $\begin{array}{l}\text { CGAP - Consultative } \\
\text { Group to Assist the Poor }\end{array}$ & 2011 \\
\hline 9 & $\begin{array}{l}\text { Why Distributing Mobile Money is Harder than } \\
\text { Airtime for MNOs }\end{array}$ & CGAP Group & $\begin{array}{l}\text { CGAP - Consultative } \\
\text { Group to Assist the Poor }\end{array}$ & 2011 \\
\hline 10 & $\begin{array}{l}\text { Mobile Money in Haiti: A Novel Approach to } \\
\text { Developing the Financial Sector }\end{array}$ & HAUSMAN, V. & The Next Billion & 2011 \\
\hline 11 & $\begin{array}{l}\text { Mobile Money in Haiti: Strategies for a Multi- } \\
\text { Competitor, Multi-Industry Market }\end{array}$ & $\begin{array}{l}\text { Hausman, Vicky; } \\
\text { Daggett, Matt; } \\
\text { Bernasconi, Lorenzo and } \\
\text { Altman, Daniel }\end{array}$ & $\begin{array}{l}\text { CGAP - Consultative } \\
\text { Group to Assist the Poor }\end{array}$ & 2011 \\
\hline 12 & $\begin{array}{l}\text { Will Brazil's agents become a channel for a wide } \\
\text { range of finan cial services for the poor? }\end{array}$ & $\begin{array}{l}\text { Kumar, Kabir and Seltzer, } \\
\text { Yanina }\end{array}$ & $\begin{array}{l}\text { CGAP - Consultative } \\
\text { Group to Assist the Poor }\end{array}$ & 2011 \\
\hline 13 & Can mobile money be "free"? & $\begin{array}{l}\text { KUMAR, Kabir; MINO, } \\
\text { Toru. }\end{array}$ & $\begin{array}{l}\text { CGAP - Consultative } \\
\text { Group to Assist the Poor }\end{array}$ & 2011 \\
\hline 14 & Five business case insights on mobile money & $\begin{array}{l}\text { KUMAR, Kabir; MINO, } \\
\text { Toru. }\end{array}$ & $\begin{array}{l}\text { CGAP - Consultative } \\
\text { Group to Assist the Poor }\end{array}$ & 2011 \\
\hline 15 & $\begin{array}{l}\text { Mobile money profitability }=\text { long term view }+ \\
\text { existing voice base }+ \text { driving electronic } \\
\text { transactions }\end{array}$ & $\begin{array}{l}\text { KUMAR, Kabir; MINO, } \\
\text { Toru. }\end{array}$ & $\begin{array}{l}\text { CGAP - Consultative } \\
\text { Group to Assist the Poor }\end{array}$ & 2011 \\
\hline 16 & $\begin{array}{l}\text { Google Wallet Kicks Off First Phase of } \\
\text { Smartphone NFC } \\
\text { Adoption }\end{array}$ & LITAN, A. HUNG M. & Gartner Inc. & 2011 \\
\hline 17 & $\begin{array}{l}\text { Delivering on the Savings Promise of Mobile } \\
\text { Money }\end{array}$ & Mas, Ignacio & $\begin{array}{l}\text { CGAP - Consultative } \\
\text { Group to Assist the Poor }\end{array}$ & 2011 \\
\hline 18 & Five Business Case Insights on Mobile Money & MINO, T. KUMAR, K. & $\begin{array}{l}\text { CGAP - Consultative } \\
\text { Group to Assist the Poor }\end{array}$ & 2011 \\
\hline 19 & Mobile Money in mHealth & Pickens, Mark & $\begin{array}{l}\text { CGAP - Consultative } \\
\text { Group to Assist the Poor }\end{array}$ & 2011 \\
\hline 20 & $\begin{array}{l}\text { Want tips on mobile money product design? Here } \\
\text { are two from a motorcy cle and a jerry can in } \\
\text { Uganda }\end{array}$ & Pickens, Mark & $\begin{array}{l}\text { CGAP - Consultative } \\
\text { Group to Assist the Poor }\end{array}$ & 2011 \\
\hline 21 & $\begin{array}{l}\text { Which Way? Mobile Money and Branchless } \\
\text { Banking in } 2011\end{array}$ & Pickens, Mark & $\begin{array}{l}\text { CGAP - Consultative } \\
\text { Group to Assist the Poor }\end{array}$ & 2011 \\
\hline 22 & $\begin{array}{l}\text { Looking for a "killer app" for the poor? Sell } \\
\text { stress reduction }\end{array}$ & Pickens, Mark & $\begin{array}{l}\text { CGAP - Consultative } \\
\text { Group to Assist the Poor }\end{array}$ & 2011 \\
\hline 23 & $\begin{array}{l}\text { The Last Frontier for Branchless Banking: State } \\
\text { of Play in WAEMU }\end{array}$ & Rotman, Sarah & $\begin{array}{l}\text { CGAP - Consultative } \\
\text { Group to Assist the Poor }\end{array}$ & 2011 \\
\hline 24 & How to run with mobile money and not fall & Shakhovskoy, Matt & $\begin{array}{l}\text { CGAP - Consultative } \\
\text { Group to Assist the Poor }\end{array}$ & 2011 \\
\hline 25 & $\begin{array}{l}\text { Cool Vendors in Consumer Mobile Services, } \\
2011\end{array}$ & $\begin{array}{l}\text { SHEN S. VERM A S. } \\
\text { ZIMMERMMAN A., } \\
\text { MCINTYRE A. }\end{array}$ & Gartner Inc. & 2011 \\
\hline 26 & $\begin{array}{l}\text { Near Field Communication is a Long-Term } \\
\text { Opportunity }\end{array}$ & SHEN, $\mathrm{S}$. & Gartner Inc. & 2011 \\
\hline
\end{tabular}




\begin{tabular}{|c|c|c|c|c|}
\hline 27 & $\begin{array}{l}\text { Visa's Fundamo Acquisition Marks the Financial } \\
\text { Inclusion of Mobile Money Services }\end{array}$ & SHEN, S. & Gartner Inc. & 2011 \\
\hline 28 & Mobile Payments go Viral: M-PESA in Keny a & $\begin{array}{l}\text { Mas, Ignacio and } \\
\text { Radcliffe, Dan }\end{array}$ & & 2010 \\
\hline 29 & Mobile money's innovation crisis & $\begin{array}{l}\text { Maurer, Bill and } \\
\text { Morawczynski, Olga }\end{array}$ & $\begin{array}{l}\text { CGAP - Consultative } \\
\text { Group to Assist the Poor }\end{array}$ & 2010 \\
\hline 30 & $\begin{array}{l}\text { Could airtime discounts kick-start mobile } \\
\text { banking? }\end{array}$ & McKay, Claudia & $\begin{array}{l}\text { CGAP - Consultative } \\
\text { Group to Assist the Poor }\end{array}$ & 2010 \\
\hline 31 & $\begin{array}{l}\text { The internet and mobile money - scenarios for } \\
2020\end{array}$ & Rotman, Sarah & $\begin{array}{l}\text { CGAP - Consultative } \\
\text { Group to Assist the Poor }\end{array}$ & 2010 \\
\hline 32 & $\begin{array}{l}\text { Count them...4 mobile money services now live } \\
\text { in Tanzania }\end{array}$ & Rotman, Sarah & $\begin{array}{l}\text { CGAP - Consultative } \\
\text { Group to Assist the Poor }\end{array}$ & 2010 \\
\hline 33 & $\begin{array}{l}\text { At Mobile World Congress, mobile banking takes } \\
\text { center stage: Portfolios of the Poor meets the five } \\
\text { firms who reach two billion customers }\end{array}$ & Rosenberg, Jim & $\begin{array}{l}\text { CGAP - Consultative } \\
\text { Group to Assist the Poor }\end{array}$ & 2010 \\
\hline 34 & $\begin{array}{l}\text { Are banks the bad guys in the mobile money } \\
\text { innovation debate? }\end{array}$ & Rotman, Sarah & $\begin{array}{l}\text { CGAP - Consultative } \\
\text { Group to Assist the Poor }\end{array}$ & 2010 \\
\hline 35 & $\begin{array}{l}\text { Can mobile money be profitable? We asked } \\
\text { mobile money managers }\end{array}$ & Baba, Karina. & $\begin{array}{l}\text { CGAP - Consultative } \\
\text { Group to Assist the Poor }\end{array}$ & 2010 \\
\hline 36 & A mobile wallet and the price of money & Bold, Chris & $\begin{array}{l}\text { CGAP - Consultative } \\
\text { Group to Assist the Poor }\end{array}$ & 2010 \\
\hline 37 & $\begin{array}{l}\text { In Afghanistan, going where no bank has gone } \\
\text { before }\end{array}$ & Bold, Chris & $\begin{array}{l}\text { CGAP - Consultative } \\
\text { Group to Assist the Poor }\end{array}$ & 2010 \\
\hline 38 & $\begin{array}{l}\text { Non Bank e-money Issuers: Regulatory } \\
\text { Approaches to Protecting Customer Funds }\end{array}$ & CGAP & $\begin{array}{l}\text { CGAP - Consultative } \\
\text { Group to Assist the Poor }\end{array}$ & 2010 \\
\hline 39 & $\begin{array}{l}\text { To what extent do the unbanked need access } \\
\text { to mobile money services? }\end{array}$ & Chipchase, Jan & $\begin{array}{l}\text { CGAP - Consultative } \\
\text { Group to Assist the Poor }\end{array}$ & 2010 \\
\hline 40 & The Rise of Mobile Money & GOLDMAN, B. & Analyst Network & 2010 \\
\hline 41 & $\begin{array}{l}\text { The birthplace of microcred it contemplates } \\
\text { mobile money }\end{array}$ & Greg Chen & $\begin{array}{l}\text { CGAP - Consultative } \\
\text { Group to Assist the Poor }\end{array}$ & 2010 \\
\hline 42 & $\begin{array}{l}\text { Dispatch from Sierra Leone: mobile money and } \\
\text { agent incentives }\end{array}$ & Lyon, Ben & $\begin{array}{l}\text { CGAP - Consultative } \\
\text { Group to Assist the Poor }\end{array}$ & 2010 \\
\hline 43 & $\begin{array}{l}\text { Branchless Banking 2010: Who's Served? At } \\
\text { What Price? What's Next? }\end{array}$ & $\begin{array}{l}\text { McKay, Claudia and } \\
\text { Pickens, Mark }\end{array}$ & $\begin{array}{l}\text { CGAP - Consultative } \\
\text { Group to Assist the Poor }\end{array}$ & 2010 \\
\hline 44 & $\begin{array}{l}\text { Mobile Money Transfer Services: The Next } \\
\text { Phase in the Evolution in Person-to-Person } \\
\text { Payments }\end{array}$ & Merritt, Cynthia & & 2010 \\
\hline 45 & The Macroeconomics of Mobile Money & NOAM, E. & $\begin{array}{l}\text { The Columbia Institute for } \\
\text { Tele-Information (CITI) }\end{array}$ & 2010 \\
\hline 46 & $\begin{array}{l}\text { Proof mobile money can make money? M-PESA } \\
\text { earns serious shillings for Safaricom }\end{array}$ & Pickens Mark & $\begin{array}{l}\text { CGAP - Consultative } \\
\text { Group to Assist the Poor }\end{array}$ & 2010 \\
\hline 47 & $\begin{array}{l}\text { Where will the next mobile money innovation } \\
\text { come from? }\end{array}$ & Pickens, Mark & $\begin{array}{l}\text { CGAP - Consultative } \\
\text { Group to Assist the Poor }\end{array}$ & 2010 \\
\hline 48 & Branchless Banking 2010: Is the hype justified? & Pickens, Mark & $\begin{array}{l}\text { CGAP - Consultative } \\
\text { Group to Assist the Poor }\end{array}$ & 2010 \\
\hline 49 & Getting Bey ond Pay ments & Pickens, Mark & $\begin{array}{l}\text { CGAP - Consultative } \\
\text { Group to Assist the Poor }\end{array}$ & 2010 \\
\hline 50 & $\begin{array}{l}\text { Mobile money takes off... where is the innovation } \\
\text { in product design? }\end{array}$ & Pickens, Mark & $\begin{array}{l}\text { CGAP - Consultative } \\
\text { Group to Assist the Poor }\end{array}$ & 2010 \\
\hline 51 & Nationwide impact of agents in Brazil & Pickens, Mark & $\begin{array}{l}\text { CGAP - Consultative } \\
\text { Group to Assist the Poor }\end{array}$ & 2010 \\
\hline 52 & $\begin{array}{l}\text { Mobile Money Innovation... waiting... } \\
\text { waiting... }\end{array}$ & Pickens, Mark & $\begin{array}{l}\text { CGAP - Consultative } \\
\text { Group to Assist the Poor }\end{array}$ & 2010 \\
\hline 53 & $\begin{array}{l}\text { O dinheiro móvel (mobile mon ey) é barato o } \\
\text { suficiente para os desbancarizados? }\end{array}$ & ROSENBERG, J. & $\begin{array}{l}\text { CGAP - Consultative } \\
\text { Group to Assist the Poor }\end{array}$ & 2010 \\
\hline 54 & $\begin{array}{l}\text { For the unbanked, is mobile money cheap } \\
\text { enough? CGAP releases pricing study across } 16 \\
\text { providers in } 10 \text { countries }\end{array}$ & Rosenberg, Jim & $\begin{array}{l}\text { CGAP - Consultative } \\
\text { Group to Assist the Poor }\end{array}$ & 2010 \\
\hline 55 & $\begin{array}{l}\text { An alternative to M-PESA? Orange and Equity } \\
\text { Bank launch Iko Pesa }\end{array}$ & Rotman, Sarah & $\begin{array}{l}\text { CGAP - Consultative } \\
\text { Group to Assist the Poor }\end{array}$ & 2010 \\
\hline
\end{tabular}




\begin{tabular}{|c|c|c|c|c|}
\hline 56 & $\begin{array}{l}\text { Who will win the mobile money game? Depends } \\
\text { on who plays }\end{array}$ & Rotman, Sarah & $\begin{array}{l}\text { CGAP - Consultative } \\
\text { Group to Assist the Poor }\end{array}$ & 2010 \\
\hline 57 & $\begin{array}{l}\text { Dakar Dispatch: Mobile money and financial } \\
\text { inclusion }\end{array}$ & Rotman, Sarah & $\begin{array}{l}\text { CGAP - Consultative } \\
\text { Group to Assist the Poor }\end{array}$ & 2010 \\
\hline 58 & $\begin{array}{l}\text { Hype Cycle for Consumer Services and Mobile } \\
\text { Applications, } 2010\end{array}$ & SHEN, S. & Gartner Inc. & 2010 \\
\hline 59 & $\begin{array}{l}\text { M-Pesa: A Case Study of the Critical Early } \\
\text { Adopters's Role in the Rapid Adoption of Mobile } \\
\text { Money Banking in Kenya }\end{array}$ & Thomas, Jeanette & $\begin{array}{l}\text { CGAP - Consultative } \\
\text { Group to Assist the Poor - } \\
\text { VIDEO }\end{array}$ & 2010 \\
\hline 60 & mWomen & & GSM Association & 2010 \\
\hline 61 & $\begin{array}{l}\text { Accelerating the Development of Mobile Money } \\
\text { Ecosy stems }\end{array}$ & Dola, Jonathan & $\begin{array}{l}\text { Harvard Kennedy School + } \\
\text { IFC / World Bank }\end{array}$ & 2009 \\
\hline 62 & $\begin{array}{l}\text { Mobile operator-centric pay ment schemes: } \\
\text { Osaifu-Keitai in Japan }\end{array}$ & Rotman, Sarah & $\begin{array}{l}\text { CGAP - Consultative } \\
\text { Group to Assist the Poor }\end{array}$ & 2009 \\
\hline 63 & $\begin{array}{l}\text { Mobile banking gets big names: Nokia, } \\
\text { Microsoft, PayPal }\end{array}$ & Pickens, Mark & $\begin{array}{l}\text { CGAP - Consultative } \\
\text { Group to Assist the Poor }\end{array}$ & 2009 \\
\hline 64 & $\begin{array}{l}\text { A view from Indonesia: Real mobile banking } \\
\text { needs solid partnerships }\end{array}$ & Rosenberg, Jim & $\begin{array}{l}\text { CGAP - Consultative } \\
\text { Group to Assist the Poor }\end{array}$ & 2009 \\
\hline 65 & $\begin{array}{l}\text { Mobile Banking in Tanzania: Concluding } \\
\text { Thoughts }\end{array}$ & Rotman, Sarah & $\begin{array}{l}\text { CGAP - Consultative } \\
\text { Group to Assist the Poor }\end{array}$ & 2009 \\
\hline 66 & Mobile payments in West Africa & Rotman, Sarah & $\begin{array}{l}\text { CGAP - Consultative } \\
\text { Group to Assist the Poor }\end{array}$ & 2009 \\
\hline 67 & MTN's recipe for mobile bank ing success & Bold, Chris & $\begin{array}{l}\text { CGAP - Consultative } \\
\text { Group to Assist the Poor }\end{array}$ & 2009 \\
\hline 68 & Mobile Banking: From Concept to Reality & CGAP & $\begin{array}{l}\text { CGAP - Consultative } \\
\text { Group to Assist the Poor }\end{array}$ & 2009 \\
\hline 69 & Seeking Fertile Grounds for Mobile Money & $\begin{array}{l}\text { Heyer, Amrik and Mas, } \\
\text { Ignacio }\end{array}$ & & 2009 \\
\hline 70 & $\begin{array}{l}\text { Do low-income mobile phone users want mobile } \\
\text { money? }\end{array}$ & Kumar, Kabir & $\begin{array}{l}\text { CGAP - Consultative } \\
\text { Group to Assist the Poor }\end{array}$ & 2009 \\
\hline 71 & New business models in mobile banking? & Kumar, Kabir & $\begin{array}{l}\text { CGAP - Consultative } \\
\text { Group to Assist the Poor }\end{array}$ & 2009 \\
\hline 72 & Mobile money by the numbers & Pickens, Mark & $\begin{array}{l}\text { CGAP - Consultative } \\
\text { Group to Assist the Poor }\end{array}$ & 2009 \\
\hline 73 & $\begin{array}{l}\text { Window on the Unbanked: Mobile Money in the } \\
\text { Philippines }\end{array}$ & Pickens, Mark & $\begin{array}{l}\text { CGAP - Consultative } \\
\text { Group to Assist the Poor }\end{array}$ & 2009 \\
\hline 74 & Microfinance, mobile banking and barangays & Santos, Maybelle & $\begin{array}{l}\text { CGAP - Consultative } \\
\text { Group to Assist the Poor }\end{array}$ & 2009 \\
\hline 75 & $\begin{array}{l}\text { GSM A Webinar - Mobile Money Pricing \& } \\
\text { Commissions }\end{array}$ & & mmublog & 2009 \\
\hline 76 & $\begin{array}{l}\text { Mobile Money: A US\$5 Billion Market } \\
\text { Opportunity }\end{array}$ & & GSMA & 2009 \\
\hline 77 & Developing Mobile Money Ecosy stems & Jenkins, Beth & $\begin{array}{l}\text { CGAP - Consultative } \\
\text { Group to Assist the Poor }\end{array}$ & 2008 \\
\hline 78 & $\begin{array}{l}\text { An Examination of Mobile Banking and Mobile } \\
\text { Pay ments: Building Adoption as Experience } \\
\text { Goods? }\end{array}$ & S. Cheney, Julia & & 2008 \\
\hline 79 & $\begin{array}{l}\text { Payment Applications Make E-Commerce } \\
\text { Mobile }\end{array}$ & Leavitt, Neal & & $\mathrm{n} / \mathrm{a}$ \\
\hline 80 & $\begin{array}{l}\text { Good things come in small packages: mobile } \\
\text { money in Fiji }\end{array}$ & Bruett,Till & $\begin{array}{l}\text { CGAP - Consultative } \\
\text { Group to Assist the Poor }\end{array}$ & $\mathrm{n} / \mathrm{a}$ \\
\hline 81 & Connectivity & & GSM Association & $\mathrm{n} / \mathrm{a}$ \\
\hline 82 & Development Found - Overview & & GSM Association & $\mathrm{n} / \mathrm{a}$ \\
\hline 83 & Financial Institutions & & GSM Association & $\mathrm{n} / \mathrm{a}$ \\
\hline 84 & Green Power for Mobile - Overview & & GSM Association & $\mathrm{n} / \mathrm{a}$ \\
\hline 85 & GSM A MMT Project & & GSM Association & $\mathrm{n} / \mathrm{a}$ \\
\hline 86 & How Pay-Buy-Mobile Works & & GSM Association & $\mathrm{n} / \mathrm{a}$ \\
\hline
\end{tabular}




\begin{tabular}{|r|l|l|l|c|}
\hline 87 & mAgri Programme & GSM Association & n/a \\
\hline 88 & Market Opportunity & GSM Association & $\mathrm{n} / \mathrm{a}$ \\
\hline 89 & mHealth - Overview & GSM Association & $\mathrm{n} / \mathrm{a}$ \\
\hline 90 & Mobile Money for the Unbanked & GSM Association & $\mathrm{n} / \mathrm{a}$ \\
\hline 91 & Mobile Money Transfer & GSM Association & $\mathrm{n} / \mathrm{a}$ \\
\hline 92 & Mobile Operators & GSM Association & $\mathrm{n} / \mathrm{a}$ \\
\hline
\end{tabular}

